\title{
La aportación de los agustinos juristas de EI Escorial a la Ciencia Jurídica española*
}

\author{
The contribution of the Augustinian jurists of El Escorial \\ to the Spanish legal science
}

\author{
Dr. Juan Ramón RODRÍGUEZ LLAMOSÍ \\ Licenciado en Derecho. Magistrado \\ Doctor en Ciencias jurídicas \\ Master en Humanidades
}

\section{A mi Carmencita. A mis hijos, Marian y Juanito.}

\begin{abstract}
Resumen: El presente trabajo es la defensa de la tesis doctoral titulada: "La aportación de los agustinos juristas de El Escorial a la Ciencia jurídica española" realizada por el autor en el Paraninfo de la Facultad de Derecho de la Universidad de Granada el día 28 de septiembre de 2018. En él se analizan brevemente las aportaciones que realizaron los agustinos juristas de El Escorial a la Ciencia jurídica española.
\end{abstract}

\footnotetext{
* El presente trabajo constituye la defensa de la tesis doctoral titulada: "La aportación de los agustinos juristas de El Escorial a la Ciencia jurídica española" realizada por el autor en el Paraninfo de la Facultad de Derecho de la Universidad de Granada el día 28 de septiembre de 2018 ante un Tribunal formado por los siguientes miembros ilustres: Don Manuel Salguero Salguero, Catedrático de Filosofía del Derecho de la Universidad de Granada (Presidente); Don Antonio Merchán Álvarez, Catedrático de Historia del Derecho y de las Instituciones de la Universidad de Sevilla (Vocal); Don Francisco Javier Campos y Fernández de Sevilla, Doctor en Filosofía y Letras (Sección Geografía e Historia) por la Universidad de Málaga, Doctor Honoris Causa en "Letras Humanas" por la Universidad Católica de Miami (Florida, USA) y por la Universidad Nacional de San Marcos de Lima (Decana de América), Académico Correspondiente de las Reales de la Historia, de la de Ciencias, Nobles Artes y Bellas Letras de Córdoba, de la de Bellas Artes de Santa Isabel de Hungría de Sevilla, y de la Academia de Historia de la Medicina del Perú y de la Peruana de Historia de la Iglesia, Bibliotecario de la Universidad "María Cristina" de San Lorenzo de El Escorial (Madrid) y Fundador y Director del Instituto Escurialense de Investigaciones Históricas y Artísticas (Vocal); Don Fernando Guanarteme Sánchez Lázaro, Catedrático de Derecho Penal de la Universidad de la Laguna (Santa Cruz de Tenerife) (Vocal); y Doña Francisca Leonor Villalba Pérez, Catedrática de Derecho Administrativo de la Universidad de Granada (Secretaria). Dicha tesis doctoral fue dirigida por la Doctora Doña María de los Ángeles Cuadrado Ruiz, profesora titular de Derecho penal de la Universidad de Granada. La mencionada tesis doctoral obtuvo la máxima calificación del Tribunal: Sobresaliente cum laude por unanimidad de todos sus miembros
} 
Abstract: The present work is the defense of the doctoral thesis entitled: "The contribution of the Augustinian jurists of El Escorial to the Spanish legal science" made by the author in the Auditorium of the Faculty of Law of the University of Granada on the 28th of September 2018. Here we briefly analyze the contributions made by the Augustinian jurists of El Escorial to Spanish legal science.

Palabras clave: agustinos, juristas, Escorial, aportaciones, Ciencia jurídica española.

Keywords: Augustinians, jurists, Escorial, contributions, Spanish legal science.

\section{Sumario:}

I. Presentación.

II. Origen de esta Tesis Doctoral.

III. Los Estudios Superiores de El Escorial.

IV. Agustinos juristas de EI Escorial.

4.1. P. Jerónimo Montes Luengos (1865-1932).

4.2. P. José López Ortiz (1898-1992).

4.3. P. Gabriel del Estal Gutiérrez (1917-2008).

4.4. P. Avelino Folgado Fernández (1917-2013).

4.5. P. Prometeo Cerezo de Diego (1938)

V. Conclusión.

Recibido: noviembre 2017.

Aceptado: enero 2018. 


\section{PRESENTACIÓN}

Con la venia Sr. Presidente. Con la venia del Tribunal.

Quiero empezar expresando mi agradecimiento a todos los miembros de este Tribunal por su aceptación para formar parte del mismo. Es para mí un verdadero honor poder defender mi tesis doctoral ante un Tribunal tan cualificado como éste. También quiero expresar mi agradecimiento a la Doctora Doña María de los Ángeles Cuadrado Ruiz, profesora titular de Derecho penal de la Universidad de Granada, que ha dirigido la tesis doctoral que voy a defender ahora ante ustedes, por su valiosa ayuda, el tiempo que me ha dedicado y el respeto que siempre ha mostrado hacia mi espacio como investigador.

La tesis doctoral que hoy pretendo defender lleva por título: "La aportación de los agustinos juristas de El Escorial a la Ciencia jurídica española".

Voy a centrar su defensa en tres aspectos: el origen y motivación de esta investigación; el contexto universitario al que se refiere; $y$, terminaré, refiriéndome brevemente a las aportaciones de los agustinos juristas de El Escorial.

\section{ORIGEN DE ESTA TESIS DOCTORAL}

Permítanme que les lea un fragmento de la emotiva carta que escribió Petrarca al monje agustino que le había regalado las Confesiones de San Agustín, tras su descenso del Monte Ventoso en la Provenza francesa. Dice así:

"Hoy, impulsado tan solo por el deseo de ver un lugar célebre por su altura, he ascendido al monte más alto de esta región, que no inmerecidamente llaman el Ventoso. Hace muchos años que tenía en mente hacerlo; ya sabes que, debido a ese destino que rige los asuntos de los hombres, desde mi infancia he vivido en esta zona, y este monte, que se ve de todas partes, lo he tenido siempre a la vista".

Esta experiencia de Petrarca ha sido común en mi vida: a los 4 años ingresé en el Colegio Valdeluz que los PP agustinos regentan en Madrid donde cursé 
mi formación escolar; y, posteriormente, ingresé en régimen de internado en el Real Colegio Universitario "María Cristina" de San Lorenzo de El Escorial, donde realicé mis estudios de Derecho. De modo que esa "zona agustiniana" ha formado parte de mi vida desde mi infancia; y aquel monte, el monte Abantos que rodea la piedra de granito de El Escorial, siempre ha estado presente en mi memoria.

Al cumplirse veinticinco años desde que terminé mis estudios de Derecho en la Universidad "María Cristina" de El Escorial, contemplando lo vivido y lo aprendido, al igual que Petrarca, en ese descenso de la vida, hice algunos estudios sobre la enseñanza del Derecho en El Escorial que me llevaron a conocer de cerca la labor de algunos juristas agustinos que permanecían en el olvido ${ }^{l}$.

La tesis doctoral que hoy defiendo quiere ser una humilde aportación al conocimiento del alma jurídica de quienes hicieron posible durante más de cien años que la enseñanza del Derecho en El Escorial fuera, no sólo una forma de enseñar, sino una forma de vida.

\section{LOS ESTUDIOS SUPERIORES DE EL ESCORIAL}

Los Estudios Superiores de El Escorial están ubicados en la ladera del Monte Abantos en San Lorenzo de El Escorial en el edificio llamado La Compaña ${ }^{2}$, un antiguo almacén y hospedería de los jerónimos, frente al Monasterio ${ }^{3}$.

\footnotetext{
${ }^{1}$ Vid. RODRIGUEZ LLAMOSI, J. R., "La enseñanza del Derecho en los Estudios Superiores del Escorial", en Anuario Jurídico y Económico Escurialense, 47 (2014) 299-322; ID., "El P. Jerónimo Montes. Un penalista inolvidable en la ciencia penal española", en La Ciudad de Dios. Revista agustiniana, 227, 3 (2014) 669-705; ID., "El P. José María López Riocerezo. Agustino, penalista y hombre de infinita bondad", en La Ciudad de Dios: Revista agustiniana, 229, 1 (2016) 189-211.

${ }^{2}$ El edificio herreriano de La Compaña del siglo XVI (1589-1596), fue construido por el arquitecto Francisco de Mora, discípulo y sucesor de Juan de Herrera, con destino a casa de servicios auxiliares del Real Monasterio de El Escorial.

${ }^{3}$ Sobre la Historia del Centro universitario puede verse: DÍFERNAN, B., Historia del Real Colegio de Estudios Superiores Universidad María Cristina de El Escorial, San Lorenzo de El Escorial, 1960; VARIOS (Ed. J. Rodríguez Díez), Los agustinos en el Monasterio del Escorial (1885-1985), San Lorenzo de El Escorial 1985; DEL ESTAL, G., Nuevo Escorial Universitario, San Lorenzo del Escorial 1986; VARIOS (Ed. F. Javier Campos y Fernández de Sevilla), Cien años de Estudios Universitarios, San Lorenzo del Escorial 1992; VARIOS (Ed. G. González del Estal), Provincia Agustiniana Matritense. Cien años de historia (18951995), San Lorenzo del Escorial 1996; RODRÍGUEZ DÍEZ, J., El Real Colegio de Estudios Superiores de El Escorial, San Lorenzo de El Escorial 1992; Idem, J., Más de Cien años de Estudios Superiores de El Escorial (Órganos de Gobierno, Profesores, Alumnos), San Lorenzo de El Escorial 1998.
} 
Se debe su existencia a la Reina regente Doña María Cristina de Habsburgo Lorena que impulsó y patrocinó su fundación con el fin de impartir las asignaturas correspondientes a la Facultad de Derecho hasta la licenciatura universitaria por lo que tomaron el nombre de Real Colegio Universitario "María Cristina"4.

Dicho Centro universitario está regentado por la orden religiosa de los agustinos desde el día 20 de diciembre del año 1892 y, para cumplir los fines fijados por la reina regente, realizaron en el edificio las reformas necesarias de estructura y acondicionamiento de aulas; nombraron con carácter provisional un rector ; y un pequeño grupo de jóvenes religiosos, con una media de 30 años, se formó para impartir la docencia en la carrera de Derecho, que se extiende ya a más de 125 años de existencia ${ }^{6}$.

En la historia del Real Colegio Universitario "María Cristina" deben destacarse tres hitos importantes que han demostrado el afán de superación de los agustinos:

1.- El primero de ellos fue la Guerra civil que, de modo violento y dramático, irrumpió en la vida comunitaria. Todos los religiosos agustinos de El Escorial fueron conducidos presos a Madrid. De los 106 que partieron, 73 murieron asesinados en Paracuellos del Jarama ${ }^{7}$. Tras la finalización de la Guerra civil, los agustinos regresaron a El Escorial y abrieron nuevamente sus puertas el 10 de enero de 1945 sin tiempo para sanar las heridas causadas ${ }^{8}$.

\footnotetext{
${ }^{4}$ Sobre la Regencia pueden verse: VARIOS, "Doña María Cristina de Habsburgo-Lorena. Estudios sobre la regencia (1885-1902) en VARIOS, (Ed. F. Javier Campos y Fernández de Sevilla) Cien años de estudios universitarios, San Lorenzo de El Escorial 1992.

${ }^{5}$ El nombramiento provisional lo fue hasta el nombramiento oficial definitivo el 26 de septiembre de 1894 del P. Francisco Javier Valdés y Noriega, quien había sido nombrado vicerrector y venía siendo hasta la fecha Director del Colegio Alfonso XII. El P. Valdés había nacido en Pola de Laviana (Asturias) en 1851. Ingresó en la orden de San Agustín en 1867, profesando en el monasterio de Valladolid. Estudió filosofia y teología. Destinado en 1874 a las Islas Filipinas, se ordena sacerdote en Manila en 1874. Destinado de nuevo a España es nombrado primer director del Colegio Alfonso XII y posteriormente de los Estudios Superiores del Escorial. En 1898 fue preconizado obispo de Puerto Rico. Perdidas estas colonias recibió el nombramiento de obispo de Jaca, siendo trasladado a la muerte del P. Cámara a la diócesis de Salamanca en 1905 hasta su fallecimiento en 1913.

${ }^{6}$ Sobre la biografía y bibliografía de los agustinos de El Escorial puede consultarse: GONZÁLEZ VELASCO, M., Autores Agustinos de El Escorial. Catálogo bibliográfico y artístico, San Lorenzo de El Escorial 1996. Dicha obra constituye el más completo catálogo de la producción literaria, bibliográfica y artística realizada por los agustinos de la Provincia Agustiniana Matritense, conocidos como agustinos de El Escorial, en los cien años de su historia, es decir, desde 1895 hasta 1995. Posteriormente el autor llevó a cabo en 2006 una segunda edición para realizar "adiciones y retoques" y corregir algunos errores del primer volumen.

${ }^{7}$ Sobre el tema puede verse: LLAMAS, J., Mártires agustinos de El Escorial, Real Monasterio de El Escorial 1949; VICUÑA, C., Mártires agustinos de El Escorial, El Escorial 1943.

${ }^{8}$ La reapertura de los Estudios Superiores en esa fecha viene motivada por la publicación de la Ley de Ordenación de la Universidad Española de 29 de julio de 1943, complementada con la Orden Ministerial de 13 de julio de 1944, por la que los Estudios Superiores del Escorial son
} 
2.- El segundo hito a destacar fue la intención de dotar de rango universitario a los Estudios Superiores de El Escorial, de conformidad con el Convenio de 5 de abril de 1962 firmado entre la Santa Sede y el Gobierno, como Universidad de la Iglesia. El P. Gabriel del Estal, entonces Prior Provincial, solicitó una entrevista con el Jefe del Estado, Francisco Franco Bahamonde, que tuvo lugar en el Palacio del Pardo el día 2 de diciembre del año 1964, y en ella éste acogió el proyecto que le presentó el Prior Provincial, dando su visto bueno. Preparados los documentos necesarios para su presentación en el Consejo de Ministros, el titular de Educación encargado de presentarlo no asistió a la sesión por encontrarse en situación de ministro dimitido, y el nuevo ministro paralizó toda actuación, lo que dio al traste con el proyecto de los agustinos. No decayeron los ánimos de los religiosos que solicitaron, no obstante, el reconocimiento oficial del centro como Colegio Universitario adscrito a la Universidad Complutense de Madrid, solicitud que fue concedida por Orden Ministerial de 26 de julio de 1971.

3.- Con el Plan Bolonia en proyecto ${ }^{9}$, y siendo rector el P. Francisco Javier Campos y Fernández de Sevilla, durante los años 1990 a 1998, a la vista de los cambios que se avecinaban, se optó por reformas estructurares de gran calado para adaptarse al nuevo Plan y a los nuevos tiempos que veían. Dichas reformas supusieron un cambio integral de las estructuras internas y, en especial, una modernización del Centro universitario mediante la reforma de las habitaciones de los alumnos, modernización de la Biblioteca, apertura de nuevas aulas, creación de una nueva Aula Magna con 426 butacas, espacios disponibles para seminarios y despachos de tutorías del profesorado y polideportivo en la montera del nuevo edificio, así como trasformación de los patios, todo ello para transformar los viejos Estudios Superiores de El Escorial en un campus académico moderno, avanzado y con vocación de futuro. De hecho, el número creciente de alumnos que durante los años de su rectorado pasaron por las aulas da buena prueba del éxito de su trabajo ${ }^{10}$.

reconocidos oficialmente y adscritos a la Universidad de Madrid, aunque las pruebas académicas y concesión de títulos estaban sometidos al Estado.

${ }^{9}$ El llamado Plan Bolonia permite unificar la valoración del alumno. Para ello se divide la enseñanza superior en tres niveles: grado, máster y doctorado. El grado, cuyo diseño queda en manos de cada universidad, tiene una duración de cuatro años, 240 créditos y sustituye a las antiguas diplomaturas y licenciaturas. El máster, en cambio, supone una especialización en un ámbito determinado o multidisciplinar, tiene una duración de un año (60 créditos) o dos (120 créditos). Y el doctorado se configura como el último escalón académico, al cual se accede a través de un máster específico y su duración es de cuatro años de promedio. La forma de medir el trabajo es los European Credit Transfer System (ETCS), que son los nuevos créditos con los que se regulan los estudios y con los que se computan no sólo las horas de clase, sino también el trabajo del alumno fuera del aula, que además pasa de ser un agente pasivo a uno activo, quien ha de contribuir mediante la asistencia a clase y la realización de trabajos a su propio aprendizaje.

${ }^{10} \mathrm{Si}$ se miran las estadísticas se comprueban los 600 alumnos de media matriculados en Derecho en los cursos 90 a 98 en que fue rector el P. Campos, con totales anuales de 1227 
La enseñanza del Derecho en los Estudios Superiores de El Escorial se ha caracterizado por dos principios metodológicos:

1.- El Humanismo cristiano que implica, siguiendo las huellas de san Agustín, un profundo amor a la Verdad desde la interioridad del hombre, y el ánimo abierto y dialogante.

2. El favorecimiento de los espacios humanísticos y estéticos de creación artística. Es característico de todos los agustinos el bagaje considerable de sabiduría y cultura que vierten en las publicaciones del colegio universitario como Nueva Etapa, (antes El Colegial) y el Anuario Jurídico y Económico Escurialense ${ }^{11}$.

Los Estudios Superiores de El Escorial han dado a España en el campo del Derecho hombres eminentes formados en sus aulas. Por citar a los más destacados señalaré: Manuel Azaña ${ }^{12}$ y Manuel Argüelles ${ }^{13}$ (Presidentes de la República), Gabriel Pastor-Díaz Galcerán (secretario de S.A.R. don Fernando), José España Serra (conde de España), José Yanguas Messía (Vizconde de Santa Clara de Avedillo), Rafael Sánchez Mazas, Dámaso Alonso, Dionisio Ridruejo, Moreno Torroba, Sánchez Tejerina, Eduardo Aunós, Alberto Alcocer, Juan Ignacio Luca de Tena, Fernández Montes, Julián Zuazo, Román Escotado, y

alumnos matriculados en el centro en el curso 94/95; 1249 alumnos en el curso 95/96; y de 1246 en el curso 96/97.

${ }^{11}$ Sobre la colaboración en esta dos revistas, así como en la también agustiniana $L a$ Ciudad de Dios puede verse la siguiente bibliografia: MUIÑOS SÁENZ, C., "La labor cientifica y literaria de los agustinos escurialenses", en Los Agustinos y el Real Monasterio de San Lorenzo del Escorial, Madrid 1910; ZARCO CUEVAS, J., Escritores agustinos del Escorial (1885-1916), Madrid 1917; LÓPEZ RIOCEREZO, J. M., "Labor jurídico-cultural de la Universidad escurialense en la Comunidad Agustiniana en el Monasterio de El Escorial", El Escorial 1964, pp. 131-166; FOLGADO FLÓREZ, S., "La producción literario-cultural de los agustinos en el Real Colegio de Estudios Superiores "María Cristina" de El Escorial”, en Anuario Jurídico Escurialense, 17-18 (1985-1986) 363-502. Corregido y aumentado en Real Colegio de Estudios Superiores de El Escorial, San Lorenzo de El Escorial 1992, pp. 475-657; GONZÁLEZ VELASCO, M., Autores Agustinos del Escorial. Catalogo Bibliográfico y Artístico, San Lorenzo del Escorial 1996, que acumula las anteriores y añade otras bibliografías y artículos.

${ }^{12}$ Ministro de la Guerra y Presidente de la República y del Gobierno tras la caída de Alfonso XIII. Conocida es la novela histórica El jardín de los frailes, escrita en 1926, donde Manuel Azaña relata sus días en El Escorial, El jardín de los frailes, Madrid 1988, pp. 23-24 y 76-77, respectivamente.

${ }^{13}$ Resulta anecdótico y se ha citado en diversos lugares que el 27 de enero de 1921 se celebró un homenaje en el Hotel Ritz de Madrid ofrecido a los 18 alumnos de María Cristina que formaban en las Cortes la llamada "minoría escurialense" compuesta de diecisiete diputados y un senador, así como el Ministro de Hacienda Manuel Argüelles y Argüelles, que había sido precisamente el primer alumno matriculado en los Estudios Superiores de Derecho justamente el año mismo de su creación. 
el actual Presidente del Gobierno Pedro Sánchez, junto a otros muchos situados en el Poder judicial, la política, la abogacía, el Notariado, los Registros, la empresa, la Administración pública, etc.

\section{AGUSTINOS JURISTAS DE EL ESCORIAL}

De aquel grupo de agustinos que abrieron las puertas de los Estudios Superiores de El Escorial para impartir la docencia jurídica hasta el momento presente merecerían destacarse para la Historia del Derecho el nombre de cinco, todos ellos doctores en Derecho, y cuyos trabajos realizados en el silencio del monacato han supuesto una importante aportación a la Ciencia jurídica española por la solvencia y prestigio de sus obras y sobre los cuales, hasta la fecha, nunca se ha realizado un estudio completo sobre la importancia que sus obras han tenido para la Ciencia jurídica española.

\subsection{P. Jerónimo Montes Luengos (1865-1932)}

1.- Agustino, doctor en Derecho y profesor de Derecho penal ${ }^{14}$.

2.- Su vida transcurre en la segunda mitad del siglo XIX y principios del siglo XX. He señalado en mi tesis doctoral el contexto histórico, ideológico

${ }^{14}$ Para una mayor amplitud sobre su biografía vid.: CAMPOS Y FERNÁNDEZ DE SEVILLA, Fco. J., "Jerónimo Montes Luengos" en Diccionario Biográfico Español, t. XXV, Real Academia de la Historia, Madrid 2012, pp. 602-603; DEL ESTAL, G., "El Padre Jerónimo Montes en la penología española, por el Padre José María López Riocerezo". Recensión, en La Ciudad de Dios, 1952, pp. 412-416; FERNÁNDEZ NúÑEZ, M. "Penalistas ilustres", en Nueva Etapa, 1-I-1912, 3; GARCÍA SUÁREZ, E. "Labor jurídico-penal del Padre Jerónimo Montes", en Religión y Cultura, 9 (1930) 211-234; GARCÍA SUÁREZ, E. "Labor jurídico penal del Padre Jerónimo Montes", en Religión y Cultura, 1932, pp. 21-55; GONZÁLEZ VELASCO, M., Autores agustinos de El Escorial, Madrid 1996, pp. 735-44; JIMÉNEZ DE ASÚA, L. "Necrología del P. Jerónimo Montes", en Revista de Derecho Público, 1932, p. 9; LÓPEZ RIOCEREZO, J. M., Labor jurídico penal del P. Agustino Jerónimo Montes en la Historia del Derecho Penal Español, Madrid 1952, p. 13; MANRIQUE, A. "Montes, Jerónimo", en Diccionario de Historia Eclesiástica de España. Madrid 1972-1975, Vol. III, pp. 1725 y ss; MARTÍNEZ GARCÍA, F. "El Derecho Penal del P. Montes", en La Ciudad de Dios, 1918, pp. 449-464; MARTÍNEZ GARCÍA, F. "Nota necrológica", en Religión y Cultura, 1932, pp. 143 y ss.; MONASTERIO, I. Místicos agustinos españoles. El Escorial 1929, Vol. II, pp. 318-324; RODRÍGUEZ LLAMOSI, J. R., "El P. Jerónimo Montes. Un penalista inolvidable en la ciencia penal española" en La Ciudad de Dios, 227, 3 (2014) 669-705; SÁNCHEZ TEJERINA, J. "Un gran penalista español: el Padre Jerónimo Montes", en Religión y Cultura, 1944, pp. 5-15; SANTIAGO VELA, G., "Ensayo de una biblioteca iberoamericana de la Orden de San Agustín. Madrid 1913-1925, Vol. V, pp. 580-585; ZARCO CUEVAS, J. Escritores agustinos de El Escorial. 1885-1916. Catálogo bio-bibliográfico. Madrid 1917, pp. 189-199. 
y jurídico porque es importante para conocer el marco en el cual se sitúa nuestro sabio agustino:

- Históricamente se trata de un periodo de tiempo caracterizado por una convulsa situación social y política entre absolutismo y liberalismo que se fueron turnando en el poder bajo el mandato de Fernando VII. Un momento crítico, lleno de inestabilidad y luchas civiles.

- Ideológicamente, Sanz del Río introdujo en España el llamado "movimiento krausista" que dividirá en dos bandos a los intelectuales españoles y despertará el espíritu crítico del alumno lejos de la política y la religión.

- Jurídicamente, no fue hasta 1842 cuando despareció la facultad de Cánones y se creó la Facultad de Jurisprudencia, donde aparece por primera vez la asignatura de Derecho penal, surgiendo los primeros nombres que formaron la primera generación de penalistas españoles. Es el caso de Luis Silvela (1839-1903), Valdés Rubio (1853-1914), Dorado Montero (1861-1919), Rovira Carrero (1870-1936), Bernardo de Quirós (1873-1959), Quintiliano Saldaña (1878-1938), Cuello Calón (1879-1963), Federico Castejón (1889-1972), Isaías Sánchez Tejerina (1892-1959) hasta llegar a Luis Jiménez de Asúa (18891970), del que fueron discípulos destacados Rodríguez Muñoz (1899-1955) y Antón Oneca (1897-1981).

En este contexto histórico, ideológico y jurídico, destacó el P. Jerónimo Montes como un penalista humanista que se interesó más por el aspecto humano y no cientifista ni positivo del Derecho penal lo que le supuso el rechazo, no sólo por sus ideas, sino como novato adolescente en una disciplina tan controvertida como la ciencia jurídico-penal, y, además, por su condición de religioso, vocación mal vista en determinados sectores laicistas de la sociedad $^{15}$.

3.- Se puede afirmar, sin caer en la exageración, que el Derecho penal no se puede escribir sin el nombre del P. Jerónimo Montes. Sus aportaciones fueron:

- La primera gran aportación del P. Montes al Derecho penal es el estudio relativo a Los principios generales del Derecho penal según los escritores del siglo $X V I^{16}$. Dicha obrita, que constituyó su tesis doctoral leída en el año

\footnotetext{
15 Téngase también en cuenta que en la propia Constitución de 30 de junio de 1876 el artículo relativo a la Iglesia Católica no estuvo exento de polémica.

${ }^{16}$ MONTES LUENGOS, J., "Los principios del derecho Penal según los escritores españoles del siglo XVI", en La Ciudad de Dios, 60 (1903) 557-64, 633-41; 61 (1903) 121-33, 301-09, 364-72, 454-463, 628-39; 62 (1903) 18-28, respectivamente.
} 
$1902^{17}$, recopila los principios generales en los cuales se sustenta el Derecho penal según nuestros antiguos teólogos del siglo XVI (como Alfonso de Castro, Domingo de Soto o Covarrubias), a los que considera iniciadores de la Ciencia del Derecho penal. Su tesis fundamental es que los principios de la Ciencia penal habían sido apuntados por los más ilustres pensadores de la Iglesia, siendo la moral la base de todas las cuestiones acerca de los delitos y las penas, lo que le permitió cuestionar la celebridad de Beccaria y la atribución a éste de la paternidad intelectual de la Ciencia del Derecho penal.

- La segunda gran aportación doctrinal del P. Montes al Derecho penal es un excelente tratado de Derecho penal titulado: Derecho penal español, que publicó en el año $1917^{18}$, con una segunda edición en el año $1929^{19}$, y que llegó a convertirse en el más importante tratado de esta materia de la época debido a la escasez de tratados en dicha materia.

La obra El derecho penal estudiado en principios y en la legislación vigente en España (1879-1884), publicada el año 1874 por Luis Silvela (1839-1903), aunque de notable importancia en las cátedras españolas, según la prensa de la época ${ }^{20}$, resultaba, sin embargo, anticuada al no incorporar las novedades del nuevo Código Penal de 1884.

Lo mismo sucedía con la obra de su sucesor en la cátedra, José María Valdés Rubio (1853-1914), titulada: Derecho penal: su filosofia, historia, legislación y jurisprudencia, publicada en 1913, que era a todas luces inadecuada para los fines didácticos, y poco recomendable por su carácter farragoso y difuso ${ }^{21}$.

De modo que, ante este panorama, sólo se contaba para la enseñanza del Derecho penal con el Curso de Derecho penal de Pedro Isaac Rovira Carrero (1870-1936) cuyo primer volumen se publicó en 1912 y el segundo se terminó tres años más tarde, en 1916, pero los dos volúmenes tan sólo comprenden la introducción y los problemas de la ley penal, por lo que volvía a ser a todas luces insuficiente.

${ }^{17}$ Dicha tesis, manuscrita por el P. Montes, es inédita y actualmente el único ejemplar de la misma se encuentra en el depósito de tesis doctorales procedentes de la Universidad de Madrid que conserva la Universidad Complutense. Consta de 150 hojas. Puede verse nuestro trabajo donde se detalla el hallazgo del citado manuscrito en RODRÍGUEZ LLAMOSÍ, J. R., "El doctorado del P. Jerónimo Montes Luengos en la Universidad Central de Madrid" en Anuario Jurídico y Económico Escurialense, 51 (2018).

${ }^{18}$ MONTES LUENGOS, J., Derecho penal español, $1^{\text {a }}$ ed. Imprenta del Real Monasterio, Madrid 1917.

${ }^{19}$ MONTES LUENGOS, J., Derecho penal español, II, 2a ed. San Lorenzo del Escorial 1929.

20 "Una obra de D. Luis Silvela", en El Imparcial (Madrid), núm. 12980, 24 de mayo de 1903.

${ }^{21}$ GARCÍA SUÁREZ, E., Op cit., p. 215. 
Aunque en 1926 apareció el Derecho penal de Eugenio Cuello Calón (1879-1963), que se adaptó mejor a las necesidades de la enseñanza de esta disciplina, y que resultó ser una obra aceptable por su exposición clara y transparente, sin embargo, a nivel doctrinal se limitaba a exponer los diferentes pareceres de las distintas escuelas sobre cuestiones concretas dejando entrever, en numerosas ocasiones, la preferencia del autor por la escuela positivista, lo que le restaba parcialidad a su exposición.

Finalmente, el Derecho penal. Contestaciones al Programa para las oposiciones al Cuerpo de Aspirantes a la Judicatura y Ministerio Fiscal, publicado en 1915 por Luis Jiménez de Asúa, no pasó de ser un temario adaptado al programa para aspirantes a la Judicatura sin contenido doctrinal.

Esta escasez de tratados penales provocó la importación de obras extranjeras traducidas al castellano, con gran esfuerzo por parte de nuestros profesores españoles, con lo que se alivió, en parte, la sequía de tratados, pero no se resolvía plenamente el problema pues dichas obras, pese a las esplendidas traducciones, no resultaban conformes con nuestras tradiciones patrias, al margen de estar plagadas de constantes anotaciones eruditas que entorpecían la lectura y el estudio ${ }^{22}$.

De este modo, se difundieron en las Universidades españolas obras como el Manual de derecho penal italiano de 1895 de Enrico Pessina (1828-1916) ${ }^{23}$, traducido por González del Castillo y adicionado por Aramburu Zuloaga y Cuello Calón; el Tratado de Derecho penal alemán de 1881 de Franz Ritter von Liszt (1851-1919) ${ }^{24}$, traducido por Quintiliano Saldaña y Jiménez de Asúa; los Principios de Derecho penal de Bernardino Alimena (1861-1915) ${ }^{25}$, formado

${ }^{22}$ El mismo P. Montes se quejaba de estas reiteradas y farragosas anotaciones en los textos y decía, no exento de toda razón, que fue un defecto muy común de las obras de Derecho, particularmente hasta mediados del siglo XVI, el de apuntalar cada palabra y cada frase, hasta la más trivial, con todo género de autoridades, resultando tal el cúmulo de citas, que hacía difícil averiguar, entre aquel laberinto de abreviaturas y números, cual es el pensamiento del autor, lo que calificaba de pésimo gusto. Y criticaba el que los escritores contemporáneos volvieran a incurrir en él. Vid. MONTES LUENGOS, J., "Introducción al estudio de la ley penal según la doctrina de los moralistas y juristas españoles", en La Ciudad de Dios, 221 (1920) 25.

${ }^{23}$ Jurista, filósofo y político italiano. Senador del Reino de Italia en el legislativo XIII.

${ }^{24}$ Jurista y político alemán de origen austríaco, conocido por sus aportaciones en el campo del Derecho Penal y del Derecho Internacional Público. Von Liszt integró la corriente "causalista naturalista" en la teoría del delito a la que también pertenece Ernst von Beling. Según los causalistas naturalistas, la acción es una causación o no evitación de una modificación (de un resultado) del mundo exterior mediante una conducta voluntaria.

${ }^{25}$ Abogado y político italiano. Profesor en la Universidad de Cagliari y luego de Módena, donde permaneció durante quince años. Nombrado primer Alcalde Electo de la ciudad de Cosenza, se convirtió en diputado elegido en Cosenza College, pero renunció al cargo a los dos meses tras ser acusado de haber obtenido financiación del Gobierno. 
por dos volúmenes publicados entre 1910-1912, cuyo primer tomo, traducido y anotado por Cuello Calón, trata fundamentalmente de la situación social del individuo antes de cometer un delito ${ }^{26}$; y el Programa del curso de Derecho criminal de Francesco Carrara (1805-1888) ${ }^{27}$, en diez volúmenes, publicado en 1859, que recogía sus once años de experiencia docente, que fue traducido y anotado por Jiménez de Asúa.

Todas estas obras, con sus traducciones y anotaciones excesivas, pero no adaptadas a nuestro Derecho nacional, hicieron necesaria la elaboración de una obra que recogiera precisamente las doctrinas tradicionales de nuestros antiguos tratadistas, pero al mismo tiempo combinara las corrientes modernas de esta disciplina para que fuera una obra fiable, definitiva y suficiente para los estudiosos de la Ciencia penal. Y en este momento de manifiesta depresión del estado de la Ciencia penal en España, el P. Montes se atrevió con una obra monumental y fundamental que es su excelente tratado titulado: Derecho penal español.

El tratado recoge las convicciones penales profundas del P. Montes asentadas sobre los principios de la Teología Moral y de la Filosofía cristiana como la libertad humana, la imputabilidad y la responsabilidad moral; las bases de orden moral de la Ciencia penal (conciencia, libertad, imputabilidad, responsabilidad, culpa, sanción, etc.); la defensa del libre albedrío como base de la imputabilidad; concibe la pena como expiación que ha de cumplir una función retributiva; aborda problemas, que son tan actuales, como la delincuencia de los menores o las medidas de seguridad; cuestiona la sentencia indeterminada; y aborda los problemas que plantea la Antropología criminal y la Sociología criminal.

- En 1897, el P. Montes publicó otra gran obra jurídica: La pena de muerte y el derecho de indulto ${ }^{28}$.

En ella analiza la legitimidad de la pena de muerte, refiere datos históricos, y termina refiriéndose a la ejecución de dicha pena, la forma, el lugar y las solemnidades con que se llevan a cabo las distintas ejecuciones.

${ }^{26}$ Lo que toma en consideración es la Antropología: el hombre que tiene sentimiento de inferioridad de tipo genético-orgánico está condicionado a cometer delitos; y la Sociología criminal: la costumbre y las leyes están implicadas dentro el código positivo, la vulneración de éstas por el individuo se da por la miseria en que se encuentra. De modo que, el individuo comete delitos en función del status que la sociedad le impone: el desempleo, la miseria y la predisposición por falta de frenos inhibitorios para cometerlos.

27 Catedrático de Derecho Penal de la Universidad de Pisa, está considerado el mayor representante de la Escuela clásica del Derecho penal italiano y se distinguió por su oposición a la pena de muerte. Tuvo influencia en la redacción del primer Código Penal italiano y en el posterior Código Penal de 1889, conocido en Italia como Código Zanardelli.

${ }^{28}$ MONTES LUENGOS, J., La pena de muerte y el Derecho de indulto, Madrid 1897. 
En la segunda parte sentó las bases del derecho de indulto. Es esta la primera y mayor defensa del derecho al indulto en nuestro país en unos momentos en los que se cuestionó con dureza dicha institución pues el pueblo seguía viendo con agrado la ejecución pública de la pena de muerte. Dicha obra es pionera en la Ciencia jurídica penal española. El P. Montes era consciente de que del mismo modo que la sociedad tiene el derecho de imponer penas a los infractores, también tiene el poder de perdonarles.

- En el año 1911 publicó el P. Montes su obra monumental titulada: Precursores de la Ciencia Penal en España. Estudios sobre el delincuente y las causas y remedios del delito ${ }^{29}$. A lo largo de sus casi 750 páginas, repletas de erudición, el P. Montes estudia las doctrinas jurídico-penales y moralistas de nuestros sabios teólogos, filósofos, juristas y moralistas de siglos pasados; analiza las causas del crimen; y, finalmente, estudia de qué modo puede realizarse la conjugación de dos conceptos esenciales en el Derecho penal como son la culpabilidad penal y la prevención.

- Cierran las aportaciones del P. Montes a la Ciencia del Derecho penal el estudio titulado: El crimen de herejía ${ }^{30}$, en el que el P. Montes consigue uno de sus mejores textos de la literatura jurídica, publicado en el año 1918, en el que trata los delitos que, en el ámbito de la herejía, podían cometerse por los infieles. Y, aunque dicho trabajo no resulta relevante en el momento actual, sin embargo, en el contexto histórico y religioso en que fue escrito supuso una importante aportación, no sólo al campo del Derecho canónico, sino también al del Derecho penal vigente en la época de su publicación, lo que le dispensó una acogida favorable.

- El P. Montes publicó otros muchos trabajos de índole histórica y jurídica en la revista La Ciudad de Dios en forma de monografías sobre los efectos obligatorios de la ley penal, la costumbre como fuente del Derecho penal, el arbitrio judicial, la ignorancia en el Derecho penal..., que iban a ser capítulos de una más amplia obra que pretendía realizar y que llevaría por título: "Historia de la Ciencia penal española”, pero la muerte no le permitió llegar a publicar.

En estos estudios trata temas de interés jurídico: En La ignorancia en el Derecho penal ${ }^{31}$ abordó la doctrina de los antiguos tratadistas acerca de la

${ }^{29}$ MONTES LUENGOS, J., Precursores de la Ciencia Penal en España. Estudios sobre el delincuente y las causas y remedios del delito, Madrid 1911.

${ }^{30}$ MONTES LUENGOS, J., El crimen de herejía (Derecho penal canónico), Madrid 1918.

${ }^{31}$ MONTES LUENGOS, J., "La ignorancia en el Derecho penal", en La Ciudad de Dios, 148 , pp. 353-369; 149, pp. 43-60, y 150, pp. 39-53, 277-297 у 321-338. 
ignorancia como excusa de la culpa y de la pena; en De re poenali ${ }^{32}$ estudia el problema de si la pena debe ser corrección o escarmiento; en "La costumbre como fuente del Derecho Penal" analizó la importancia de la costumbre y su validez en el Derecho penal ${ }^{33}$; en la "Introducción al estudio de la ley penal según las doctrinas de los moralistas y jurisconsultos españoles "34, parte de la existencia de una Ley natural objetivamente inmutable, derivada de la naturaleza racional del hombre y superior a toda ley humana, fuente y norma del Derecho positivo. Y siguen otros estudios donde siguió abordando las cuestiones que quería que formaran parte de la investigación histórico penal: Valor científico de la defensa social en la penalidad ${ }^{35}$, El arbitrio judicial en la determinación de la pena ${ }^{36}$, etc.

\subsection{P. José López Ortiz (1898-1992)}

1.- Agustino. Catedrático de Historia del Derecho en la Universidad de Santiago; Catedrático de Historia de la Iglesia y del Derecho Canónico en la Universidad Central (hoy Complutense de Madrid); Obispo de Tuy y Vicario General Castrense y Arzobispo de Grado ${ }^{37}$.

${ }^{32}$ MONTES LUENGOS, J., "De re poenali. ¿La pena debe ser corrección o escarmiento?”, en La Ciudad de Dios, 90, pp. 433-44; “De re poenali. El problema del castigo corporal”, en La Ciudad de Dios, 91, pp. 12-25.

${ }^{33}$ MONTES LUENGOS, J., "La costumbre como fuente del Derecho Penal”, en La Ciudad de Dios, 120, pp. 218-34, 350-67.

${ }^{34}$ MONTES LUENGOS, J., "Introducción al estudio de la ley penal según las doctrinas de los moralistas y jurisconsultos españoles", en La Ciudad de Dios, 121, 122, 130, 131, 132135 y 140.

${ }^{35}$ MONTES LUENGOS, J., "Valor científico de la defensa social en la penalidad", en $L a$ Ciudad de Dios, 109, pp. 5-27.

${ }^{36}$ MONTES LUENGOS, J., "El arbitrio judicial en la determinación de la pena”, en $L a$ Ciudad de Dios, 120, pp. 5-22 y 117-32.

${ }^{37}$ El estudio biográfico más exhaustivo que se puede consultar es el realizado por GONZÁLEZ VELASCO, M., “Fray José López Ortiz (1898-1992), en Anuario Jurídico y Económico escurialense, 26/1 (1993), pp. 13-110. Es además de un estudio biográfico, un estudio biobliográfico que enumera todas las publicaciones de carácter biográfico. También se puede ver PELÁEZ, M. J. (ed.), Diccionario Crítico de Juristas españoles, portugueses y latinoamericanos, Vol. I, Barcelona, Universidad de Málaga, Servicio de Publicaciones, 2005, pp. 493-494. En el mismo sentido, vid. "López Ortiz, José Ángel (fray José López Ortiz, O.S.A.)”, en PEIRÓ, I - PASAMAR, G., (eds.) en Diccionario Akal de historiadores españoles, Madrid, Akal, 2002, pp. 363-364; ORLANDO, J., "Fray José López Ortiz, OSA (1898-1992)" en Archivo Histórico del Derecho Español, 63-64 (1993-1994) 1401-1403; ANDIÓN MARIAN, J., "El magisterio de fray José López en la Diócesis de Tuy-Vigo", en Anuario Jurídico y Económico Escurialense, 36-1 (1993) 145-167; CASTAÑO DE LA PUENTE, F., "Ilmo. y Rvmo. Sr. Dr. Fray José López Ortiz", en Historia del Real Colegio de Alfonso XII, San Lorenzo de El Escorial 1996, t. I, pp. 1026-1055; GIBERT, R., "Recuerdos de fray José López Ortiz”, en Anuario Jurídico y Económico escurialense, 36-1 (1993) 203-204. 
2.- Sus aportaciones a la Ciencia jurídica española se pueden agrupar en tres bloques: al Derecho Canónico; al Derecho medieval; y a la Historia del Derecho.

- Al Derecho canónico ${ }^{38}$ : realizó estudios sobre el Doctor Navarro Martín de Azpilicueta ${ }^{39}$, y sobre los cluniacenses y la abolición del reconocimiento mozárabe ${ }^{40}$, donde analizó la supresión del antiguo rito hispánico que formó parte del grupo de liturgias de lengua latina entre los siglos V y VII en Occidente y la intervención que tuvieron los cluniacenses. Asimismo, para facilitar el estudio de los alumnos publicó un manual de Historia del Derecho Canónico ${ }^{41}$.

- Al Derecho medieval: realizó estudios de temas de historia jurídica española tratando de hablar del espíritu de las instituciones jurídicas del pasado. A este segundo aspecto corresponden los siguientes trabajos destacados: "Las versiones castellanas escurialenses",42, "El proceso en los reinos cristianos de nuestra Reconquista antes de la recepción romano-canónica"43. "Las Leyes Nuevas" y "El tránsito de la justicia privada a la pública en la Edad Media" " "Notas para el estudio de la idea imperial leonesa",45 ; "Las ideas imperiales en el Medioevo español "46, donde pone de manifiesto el problema de la construcción del Imperio medieval español.

${ }^{38}$ Se custodia el original de la Memoria explicativa de los méritos y trabajos alegados para el Concurso a la Cátedra de Historia de la Iglesia y del Derecho Canónico presentada por el candidato fray José López Ortiz en el Archivo General de la Administración de Alcalá de Henares, sección de Educación y Ciencia, Caja 1529, documento suelto. Dicho documento, inédito hasta el momento, fue publicado y corregido en su ortografía por PELÁEZ, M. J., "La enseñanza de la Historia de la Iglesia". Puede leerse en: https://dadun.unav.edu/bitstream/10171/ 5260/1/MANUEL\%20J.\%20PELAEZ.pdf, pp. 497-501.

${ }^{39}$ LÓPEZ ORTIZ. J., "Un canonista español del siglo XVI, el Doctor Navarro D. Martín de Azpilicueta" en La Ciudad de Dios 153 (1941) 271-302. Martín de Azpilicueta (1492-1586) o Doctor navarrus, fue un filósofo, religioso y teólogo navarro y uno de los más importantes intelectuales de su tiempo. El P. López Ortiz, hace una minuciosa semblanza de él, considerado a la vez como teólogo, jurisconsulto y economista, autor de numerosos ensayos pues perteneció a la llamada Escuela de Salamanca junto con otros jesuitas, dominicos y franciscanos para profundizar en la significación científica que para el Derecho eclesiástico tuvo en la tradición cultural de Europa y la tradición canónica de su tiempo.

${ }^{40}$ LÓPEZ ORTIZ. J., "Sobre los cluniacenses y la abolición del reconocimiento mozárabe", en Haz, mayo de 1934, pp. 30-31.

${ }^{41}$ LÓPEZ ORTIZ. J., "Prólogo" en Derecho Canónico, Madrid 1947, p. XV.

${ }^{42}$ LÓPEZ ORTIZ. J., "Las versiones castellanas escurialenses de interés jurídico recientemente publicadas", en Religión y Cultura, 38 (1932) 111-21.

${ }^{43}$ LÓPEZ ORTIZ. J., "El proceso en los reinos cristianos de nuestra Reconquista antes de la recepción romano-canónica”, en Anuario de Historia del Derecho Español, 14 (1942-43) 184-226.

${ }^{44}$ Se trata de obras que se perdieron.

${ }^{45}$ LÓPEZ ORTIZ. J., "Notas para el estudio de la idea imperial leonesa", en La Ciudad de Dios, 153 (1941) 186-ss.

${ }^{46}$ LÓPEZ ORTIZ. J., "Las ideas imperiales en el Medioevo español”, en Escorial 1942, pp. $43-70$. 
- Su principal aportación a la Historia del Derecho fueron sus estudios sobre el Derecho musulmán.

Estaba dotado de una extremada facilidad para el manejo de las lenguas extranjeras pues, junto al dominio del alemán, francés, inglés, italiano, y arameo, hablaba perfectamente la lengua árabe con sus ocho dialectos, lo que le permitió ser un profundo conocedor de la lengua y la literatura islámica y profundizar en el estudio de esta materia.

El P. López Ortiz, consciente de que los ocho siglos de permanencia de los musulmanes en España hasta 1492, en que los Reyes Católicos toman Granada, último reducto en poder de los musulmanes, imponiendo la fe católica en toda España, produjo consecuencias a todos los niveles (políticas, jurídicas, culturales y religiosas) se dedicó al estudio del Derecho musulmán, lo que le consagró como el primer jurista español especialista en dicha materia y le llevó a ser considerado el pionero del arabismo español en su dimensión jurídica ${ }^{47}$.

Hemos encontrado materiales que permiten afirmar la existencia de un grupo de estudiosos dedicados a la cuestión jurídica del arabismo. Y sería interesante un estudio de sus relaciones. Así destacamos a: Pascual de Gayangos y Arce

${ }^{47}$ La citada expresión "arabismo en su dimensión jurídica" fue acuñada en la Segunda Semana de Historia del Derecho convocada por iniciativa del Anuario de Historia del Derecho y bajo el doble patrocinio del Instituto Nacional de Estudios Jurídicos y del Consejo Superior de Investigaciones Científicas celebrado en Madrid los días 9 al 15 de diciembre de 1948. Dicho acontecimiento fue presidido por el profesor José Castán Tobeñas (1889-1969), eminente jurista español especialmente destacado por sus trabajos sobre el Derecho Civil, que llegó a ser Procurador en las Cortes Españolas durante las nueve primeras legislaturas del período franquista. En dicho acto intervinieron diferentes profesores universitarios, investigadores y personalidades de diferentes profesiones del derecho como Galo Sánchez, Ramón Prieto Bances, Vladimiro Vince, Joaquín Cerdá, Isamel Sánchez Bella, Guillermo Céspedes del Castillo, Rafael Gibert, Alfonso García Gallo, Jaime Guasp y el magistrado Federico Castejón. La reunión tenía como objetivo hacer posible un contacto personal entre los estudiosos e interesados en la Historia del Derecho y un intercambio sobre los diferentes puntos de vista de la Historia del Derecho español a fin de contribuir con sus trabajos a la gran tarea de la tradición y la renovación jurídica de nuestro país, oficiándose por el P. López Ortiz, ya Obispo de Tuy, una misa en la Iglesia de San Manuel y San Benito de Madrid por las almas de los profesores fallecidos. Cuando el P. López Ortiz intervino pronunció una conferencia titulada: Las investigaciones del Derecho musulmán y la Historia jurídica española, en la cual expuso un resumen de sus años de aprendizaje y trabajo consagrados a esta especialidad, a la que el autor quiso dar el carácter de despedida de todas las etapas de tanteos y ensayos dedicados a esta especialidad, poco cultivada y con métodos muy desencaminados. Los asistentes apreciaron de tal modo sus aportaciones realizadas para el futuro de los que prosiguieran por este camino tan poco transitado que le dieron el título de "fundador del arabismo español" en su dimensión jurídica. Vid. Vid. S (sic) "Segunda semana en Historia del Derecho", en Anuario de Historia del Derecho español, 19 (1948-1949) 871-876. 
(1809-1897); Francisco Codera Zaidín (1836-1917); Eduardo de Hinojosa y Naveros (1852-1919); Rafael de Ureña y Smenjaud (1852-1930); Julián Ribera y Tarragó (1858-1934); Francisco Pons Boigues (1861-1899); Mariano Gaspar Remiro (1868-1925); Miguel Asín Palacios (1871-1944) (formó a tres agustinos como arabistas: Melchor Martínez Antuña, Nemesio Morata y, nuestro autor, José López Ortiz); Maximiliano Agustín Alarcón Santón (1880-1933); Ángel González Palencia (1889-1949); Claudio Sánchez Albornoz (1893-1983); Luis Seco de Lucena y Paredes (1901-1974); Salvador Vila (1904-1936), Rector de la Universidad de Granada, fusilado en Viznar ${ }^{48}$.

Las aportaciones en este ámbito pueden reducirse en tres grupos:

a.- Los documentos notariales, las fatwas y los jurisconsultos musulmanes.

Pertenecen a este grupo aquellas investigaciones que tienen por objeto, a partir del estudio de los documentos notariales y las fatwas, conocer la sociedad musulmana durante la invasión y aportar datos para el conocimiento de los jurisconsultos musulmanes.

Fatwa (fatua o fetua) es la respuesta del mufti a una pregunta formulada individualmente o en grupo, sin referencia a personas concretas en las que el jurisconsulto da una explicación sobre las prescripciones de la ley aplicable a un caso concreto según la escuela jurídica a la que pertenece.

El muftí era el jurisconsulto especialista en el fiqh (derecho) y su aplicación, responsable de interpretar la ley y emitir respuestas doctrinales sobre cuestiones pertenecientes al Derecho musulmán y sobre las cuales era consultado por un particular, una institución o un cadí.

El P. López Ortiz tenía la firme convicción, que resultó acertada, de que la única forma en que se podría conocer cómo era la sociedad musulmana durante la invasión era mediante el estudio de los documentos notariales y las fatwas, llegando a realizar traducciones de importantes manuscritos árabes y poniendo de relieve la figura de importantes y destacados jurisconsultos en la ciencia jurídica musulmana como Abenmsalmún de Granada, Yahya ben Yahya, Abenhabid, Ibn Alqama, Ibn Salmum e Ibn-al-Attar.

${ }^{48}$ Para hablar de los orígenes del arabismo español hay que acudir a la obra de Manuela Manzanares de Cirre titulada Arabistas españoles del siglo XIX, publicada por el Instituto Hispano-Árabe de Cultura en 1972, con interesante prólogo del profesor Pedro Chalmeta y una bibliografía muy detallada que es hasta el momento la obra más completa. Posteriormente se han publicado estudios sobre las principales figuras del arabismo original como las ediciones de María Jesús Viguera, Cristina Álvarez Muillán, Manuela Marín, además de Bernabé López García. 
En este grupo merecen destacarse principalmente los siguientes trabajos: "Formularios notariales de la España musulmana"49; "Algunas capitulos del Formulario Notarial de Abenmsalmún de Granada" "Fotwas granadinas de los siglos $X I V y X V^{, 51}$.

b.- Las escuelas jurídicas. La escuela malequí.

Señala el P. López Ortiz, cómo hacia el siglo IX se reconocen cuatro maneras de interpretación y creación del Derecho musulmán que dan lugar a las cuatro escuelas jurídicas: la escuela malikí, hanifí, safií y hanbalí.

En su tesis doctoral, original y novedosa, defendida en la Universidad Central de Madrid (hoy UCM), en 1931, titulada: "La recepción de la escuela malequi en España" 52 , sostiene que en la España musulmana predominó la escuela malekita fundada por Malik Ibn Anas de la escuela de Medina y preconizada por el emir Hisham I.

c.- El Derecho musulmán.

El P. López Ortiz dedicó un trabajo amplio a la materia a modo de manual o tratado titulado: "Derecho musulmán" "53, que es una exposición de conjunto del Derecho musulmán. En él, el P. López Ortiz analiza el sistema jurídico musulmán examinando el Derecho del Islam y la estructura económica de los territorios musulmanes, seguido de cuatro partes: la primera, dedicada a las Fuentes del Derecho musulmán; la segunda, al Derecho público; la tercera, al Derecho ritual, y, la última, al Derecho privado. Finaliza con un Índice Analítico y otro Onomástico.

También examinó la relación entre las obras jurídicas y el Derecho vivido a partir del estudio de la práctica de los Tribunales. Sobre temas de la Administración de justicia musulmana publicó: "El Tribunal de fe de los

${ }^{49}$ LÓPEZ ORTIZ. J., "Formularios notariales de la España musulmana", en La Ciudad de Dios 145 (1926) 260-75.

${ }^{50}$ LÓPEZ ORTIZ. J., "Algunas capítulos del Formulario Notarial de Abensalm de Granada, en Anuario de Historia del Derecho Español, IV (1927) 319-75. Se trata de la edición de un formulario inédito, con una excelente traducción y comentario.

${ }^{51}$ LÓPEZ ORTIZ, J., "Fatwás granadinas de los siglos XIV y XV", en Al-Ándalus, VI (1941) 73-127.

${ }^{52}$ LÓPEZ ORTIZ, J., La recepción de la escuela maleki en España, Madrid 1931. Ésta tesis, que tuvo una gran aceptación en los medios jurídicos y científicos donde se dio a conocer, fue el resultado de una beca concedida por la Junta de Ampliación de estudios, lo que le permitió profundizar en el estudio de la cultura árabe en las Universidades de Murcia, Wurzburg y Berlín.

${ }^{53}$ LÓPEZ ORTIZ, J. Derecho musulmán, Madrid 1932. 
Omeyas Cordobeses" 54 ; "La curia musulmana" "55; "La jurisprudencia y el estilo de los Tribunales musulmanes en España" "F6. "Fatwas granadinas de los siglos $X I V$ y XV"57; y "El Derecho musulmán en la investigación alemana de la postguerra" ${ }^{, 58}$.

Otra gran aportación a la Historia del Derecho español realizada por el P. López Ortiz en materia del Derecho musulmán fue la de rescatar del olvido las figuras de destacados juristas de la curia musulmana ${ }^{59}$ : Abenmsalmún de Granada $^{60}$; Yahya ben Yahya ${ }^{61}$; Abenhabid ${ }^{62}$; y Ibn Alqama ${ }^{63}$. Especialmente, deben destacarse, por exhaustividad de nuestra tesis: Ibn Salmum e Ibn-al-Attar.

\section{3.- Influencias del P. José López Ortiz}

El legado del P. López Ortiz ha llegado hasta nuestros días. Así han surgido nuevas generaciones de investigadores sensibles hacia el arabismo jurídico. En este aspecto, no podemos olvidar los importantes estudios realizados por la nueva escuela de arabistas españoles con autores destacados como María Jesús Viguera $^{64}$; David Peláez Portales ${ }^{65}$; José Aguilera Pleguezuelos ${ }^{66}$; Juan Martos

${ }^{54}$ LÓPEZ ORTIZ. J., "El Tribunal de fe de los Omeyas Cordobeses", en Cruz y raya, mayo de 1933, pp. 37-59.

${ }^{55}$ LÓPEZ ORTIZ. J., "La curia hispano-musulmana”, en Religión y Cultura, 6 (1929) 66-81.

${ }^{56}$ LÓPEZ ORTIZ. J., "La jurisprudencia y el estilo de los Tribunales musulmanes en España", en Anuario de Historia del Derecho Español, 9 (1932) 213-48.

${ }^{57}$ LÓPEZ ORTIZ. J., "Fatwas granadinas de los siglos XIV y XV", en Al-Ándalus, 4 (1941) 73-127.

${ }^{58}$ LÓPEZ ORTIZ. J., "El Derecho musulmán en la investigación alemana de la postguerra”, en Religión y Cultura, 10 (1930) 412-24.

${ }^{59}$ LÓPEZ ORTIZ, J., Los jurisconsultos musulmanes. Tirada aparte de Religión y Cultura, El Escorial 1930.

${ }^{60}$ LÓPEZ ORTIZ, J., "Algunos capítulos del formulario notarial de Abensalmún de Grandada", en Anuario de Historia del Derecho Español, 4 (1927) 319-375

${ }^{61}$ LÓPEZ ORTIZ, J., "Figuras de jurisconsultos hispano-musulmanes: Yahya ben Yahya", en Religión y Cultura, 16 (1931) 94-105.

${ }^{62}$ LÓPEZ ORTIZ, J., "Figuras de jurisconsultos hispano-musulmanes: Abenhabid", en Religión y Cultura, 17 (1932) 186-198.

${ }^{63}$ LÓPEZ ORTIZ, J., "La filosofía de la historia de Ibn Alqama, cronista musulmán del Mío Cid", en Mio Cid 1934.

${ }^{64} \mathrm{Ha}$ publicado hasta la fecha 55 libros, ediciones, traducciones y libros colectivos, entre ellos los volúmenes VIII-1, 2, 3 y 4 de la Historia de España de Menéndez Pidal; también, 257 artículos y capítulos de libros, sobre diversos aspectos de la Historia de Al-Ándalus y del Magreb, sobre todo acerca de la historia política de los períodos de taifas, y sobre los componentes de la sociedad andalusí, y sus componentes religiosos y culturales.

${ }^{65}$ PELÁEZ PORTALES, D., La administración de Justicia en la España musulmana, Córdoba 1999.

${ }^{66}$ AGUILERA PLEGUEZUELO, J., Estudio de las normas e instituciones de derecho islámico en Al-Ándalus, Sevilla 2000. 
Quesada $^{67}$; Magdalena Martínez Almira ${ }^{68}$; Bruno Aguilera Barchet ${ }^{69}$; Alejandro Martínez Dhier ${ }^{70}$; P. Chalmenta y F. Corriente ${ }^{71}$; E. Viguera Franco ${ }^{72}$; V. Flórez de Quiñones ${ }^{73}$; P. Mandirola Brieux ${ }^{74}$ y Manuela Manzanares de Cirre $^{75}$, entre otros.

También merece destacarse la labor de las Universidades en sus departamentos de árabe con la creación de bibliotecas especializadas e institutos que impulsan una gran actividad de conocimiento y divulgación como la reciente puesta en marcha de la llamada Biblioteca de Al-Ándalus ${ }^{76}$.

Mencionar, asimismo, la publicación actual de tres importantes diccionarios: el Diccionario de Derecho islámico de Felipe Maillo Salgado ${ }^{77}$; el Diccionario jurídico español/árabe de Abdellatif Aguessim El Ghazouani ${ }^{78}$; y, el Diccionario de términos jurídicos árabe-español ${ }^{79}$. Estos diccionarios han cubierto el vacío existente que tenían los investigadores de diccionarios específicos sobre el campo jurídico.

${ }^{67}$ MARTOS QUESADA, J., "Islam y Ciencia en Al-Ándalus", en 'llu. Revista de Ciencias de las Religiones, Anejos XVI (2006) 75-92; Introducción al mundo jurídico de la España musulmana, Madrid 1999; "El Corán como fuente del Derecho en el Islam", en Cuadernos de Historia del Derecho XI (2004), pp. 327-338; “Islam y derecho: las escuelas jurídicas en Al-Ándalus”, en Arbor, 731 (2008) 433-442.

${ }^{68}$ MARTÍNEZ ALMIRA, M., "Estudios e investigaciones sobre las fuentes, derecho privado, penal y procesal islámico", en Al-Ándalus; "Una aproximación historiográfica”, en Interpretatio, 8 (2002) 19-173; y Derecho procesal maliki hispanoárabe, Nápoles 2006, pp. 15-40.

${ }^{69}$ AGUILERA BARCHET, B., Iniciación histórica dal Derecho musulmán, Madrid 2007.

70 MARTÍNEZ DHIER, A., "Algunas consideraciones sobre la Historia del Derecho musulmán en España”, en Historia. Instituciones. Documentos, 34 (2007) 189-206. Se trata de un Comentario, no exhaustivo, a propósito de la obra de AGUILERA BARCHET, B., Iniciación histórica al Derecho musulmán. Seguida de un ensayo sobre la historia jurídica de Al-Ándalus, Madrid 2007, en el que dedica su atención en aquellos autores que se han dedicado: "al cultivo y análisis de las fuentes e instituciones del derecho islámico en sus múltiples facetas", p. 189.

${ }^{71}$ CHALMETA, P. y F. CORRIENTE, Formularios notariales hispano musulmanes, Madrid 1983.

${ }^{72}$ VIGUERA FRANCO, E., "Derecho musulmán de la escuela malequita en Occidente" en Iustitia, Boletín Oficial del Ministerio de Justicia, VIII (1944) 5-16.

73 FLÓREZ DE QUIÑONES, V., "Formularios notariales hispano-musulmanes", en Anales de la Academia Matritense del Notariado, XXII (1977).

${ }^{74}$ MANDIROLA BRIEUX, P., Introducción al derecho islámico, Madrid 1998.

${ }^{75}$ MANZANARES DE CIRRE, M., Arabistas españoles en el siglo XIX. Madrid 1972.

${ }^{76}$ Conviene citar, acaso, los más importantes: Instituto de Cooperación con el Mundo Árabe; Escuela de Estudios Árabes de Granada; Instituto Egipcio de Estudios Islámicos; Centro de Información y Documentación Africanas; Centro de Estudios Árabes y Arqueológicos "Ibn 'Arabí' de Murcia; Biblioteca del Real Monasterio de El Escorial.

${ }^{77}$ MAILlO SALGADO, F., Diccionario de Derecho islámico, Gijón 2005.

${ }^{78}$ AGUESSIM EL GHAZOUANI, A., Diccionario jurídico español/árabe, Granada 2006.

${ }^{79}$ FERIA GARCÍA, M. C., Diccionario de términos jurídicos árabe-español, Barcelona 2006. 
Con todo ello, queda patente que aquellos iniciales estudios del P. López Ortiz no cayeron en saco roto y han dado su postrer fruto. Los investigadores no han escatimado sus esfuerzos para abordar y seguir reconstruyendo seriamente el legado hispano-musulmán, dando el impulso necesario a los primitivos estudios realizados por el sabio agustino. Basta echar una ojeada a la extensa bibliografía, tanto española como extranjera, que ha aparecido en los últimos años para poder afirmar el interés creciente por estos temas de nuestros investigadores con la publicación de tesis doctorales, traducciones, textos de literatura árabe, historia clásica o moderna del Islam, así como la aparición de numerosas revistas especializadas sobre la materia ${ }^{80}$.

\subsection{P. Gabriel del Estal Gutiérrez (1917-2008)}

1.- Agustino, Rector de los Estudios Superiores del Escorial y Prior provincial de la Orden agustiniana, pero sobre todo fue un humanista ${ }^{81}$, un sabio, un

${ }^{80}$ Deben citarse, entre las más importantes: Al Árabí, Al-Qantara, Awraq, Cuadernos de Historia del Islam, Cuadernos de la Alambra, Boletín de la Asociación española de Orientalistas; Omaya, etc.

${ }^{81}$ El P. Gabriel del Estal se mostró como un claro defensor a ultranza del humanismo teológico y cristiano que matizó con su raíz agustiniana y escribió interesantes y bien nutridos ensayos sobre el tema: DEL ESTAL, G., Estudios sobre "La ciudad de Dios" de San Agustín. La Ciudad de Dios, Madrid 1954, 167, Número extraordinario de la revista La Ciudad de Dios en el XVI centenario del nacimiento de San Agustín, 2 vols.; ID., "San Agustín y el único agustinismo", en La Ciudad de Dios, 1954, pp. 5-24; IDEM, "San Agustín y su invitación a la interioridad", en Ecclesia, Madrid, 1954, pp. 404-406; IDEM, "La Ciudad de Dios" de San Agustín ante el curso de los tiempos. Historia. Filosofía de la Historia. Filosofía cristiana de la Historia, en La Ciudad de Dios, Madrid 1954, número extraordinario, vol. I, pp. 207-283; IDEM, "Equivalencia de civitas en el De civitate Dei", en La Ciudad de Dios, Madrid 1954, número extraordinario, vol. II, pp. 356-454; IDEM, "Perfil humano de San Agustín", en Ecclesia, Madrid 1954, pp. 600-602; IDEM, "Después del centenario de San Agustín", en La Ciudad de Dios, 1955, pp. 5-9; IDEM, "San Agustín: jerarquía y totalidad", en Augustinus, Madrid 1956, pp. 9-21; IDEM, "La idea de los dos reinos en la dialéctica de San Agustín. Resumen de tesis doctoral", en Revista de la Facultad de Derecho, Universidad Complutense de Madrid, 1 (1957) 237-239; IDEM, "Derecho y Estado en la concepción agustiniana de las dos civitates", en Boletín del Ilustre Colegio de Abogados de Madrid, enero-febrero (1958) 13-15; IDEM, "Santa Mónica: perfil biográfico", en Año Cristiano, Madrid, II (1959) $277-$ 288; IDEM, "La dialéctica de los dos reinos en la filosofía agustiniana del Derecho y del Estado. Parte sistemática", en La Ciudad de Dios, 1959, pp. 5-72; IDEM, "San Agustín y El Escorial. Razón y tiempo de La Ciudad de Dios", en Nueva Etapa, 47 (1981) 73-77; IDEM, Augustine's Concept of the Just War, en Nueva York: N. B. Franklin House, 1985, pp. 302307; IDEM, "El concepto de San Agustín de la guerra justa", en Saint Augustine, Father of European and African Civilization. International Conference of the Schiller Institute, November 13, 1985 in Rome. Nueva York: N. B. Franklin House, 1985, pp. 61-67; IDEM, "St. Augustine, realistic pacitism, and the Strategig Defense Initiative, en ElR, Executive Intelligence Review, Washington, 47 (1985) 53-55; IDEM, "Frente al pacifismo utópico y manipulado, el 
intelectual, un poeta sublime ${ }^{82}$, un político de raza dotado de mando y buen gobierno $^{83}$, y perito en vientos: dominaba las velas del trivium y el cuadrivium y podía navegar aproando rumbo al saber infinito con brisa a su favor. Entendía el secreto de las estrellas y la profundidad de Dios. En su ordenada mente estaba la tragedia griega, la piedra filosofal y el mundo de las siete esferas transparentes. Y, creemos, que debía tener noticias del mar de lodo en el que Platón disuelve la Atlántida ${ }^{84}$.

pacifismo realista de San Agustín”, en Benegeli, Revista de Arte, Ciencia y Buen gobierno, México, 2 (1986) 44-47.

82 DEL ESTAL, G., "Memento", en Bosquecillo, El Escorial, 1942, pp. 30-31; ID, "Retorno. Canto a la nueva España" en El Colegial, El Escorial 1943, pp. 12-13; IDEM, "Saludo de turrón", en Bosquecillo, El Escorial, 2 (1943) 30; IDEM, "El Arce del Bosque", en Bosquecillo, El Escorial, 2 (1943) 41-43; IDEM, "Sembrar", en Bosquecillo, El Escorial, 2 (1943) 30; IDEM, "A vosotros", en El Colegial, El Escorial 1944, p. 2; IDEM, "Un retrato", en Bosquecillo, El Escorial, 10 (1944) 21; IDEM, "Pax hominibus", Bosquecillo, El Escorial, 10 (1944) 31-32; IDEM, "Novicio del Escorial", en Bosquecillo, El Escorial, 10 (1944) 41-46; IDEM, "Himno del Colegio Alfonso XII", en El Colegial, 1945, p. 41; IDEM, "El abrazo del ángel", en Bosquecillo, El Escorial, 1946, p. 21; "IDEM, "Dolorosa" en Bosquecillo, El Escorial, 1946, p. 69-70; IDEM, "A la puerta de mi casa", en Bosquecillo, El Escorial, 1946, p. 89; IDEM, "Sombra eucarística", en Bosquecillo, El Escorial, 1946, p. 53; IDEM, "Mi regalo" en Bosquecillo, El Escorial, 1946, p. 145; IDEM, "Nocturno", en Bosquecillo, El Escorial, 1946, p. 148; IDEM, "El éxtasis de Ostia (soneto a san Agustín" en Bosquecillo, El Escorial, 29 (1946) 11; IDEM, "Tríptico de sonetos", en Bosquecillo, El Escorial, 29 (1946) 16-17; IDEM, "La conversión del genio", en Bosquecillo, El Escoria,1 1951, p. 223; IDEM, "Luz en la noche", en Bosquecillo, El Escorial, 1951, p. 268-269; IDEM, "Fronda y piedra", en Bosquecillo, El Escorial, 1952, pp. 175176; IDEM, "Nunca es tarde" en Bosquecillo, El Escorial, 81 (1952) 289; IDEM, "Navidad" en Bosquecillo, El Escorial, 81 (1952) 406-11; IDEM, "El redentor con estrellas", en Bosquecillo, El Escorial, 1953, p. 56; IDEM, “Zapatito azul”, en Bosquecillo, El Escorial, 1953, p. 18; IDEM, "Romanza de Reyes", en Bosquecillo, El Escorial, 1954, p. 12; IDEM, "Una medalla", en Bosquecillo, El Escorial, 1961, p. 308.

${ }^{83} \mathrm{Y}$ es que el P. Gabriel del Estal llevó a cabo una profunda renovación de la Provincia agustiniana matritense, mediante la puesta en marcha de Centros educativos (Colegio Valdeluz de Madrid, Colegio Los Olivos de Málaga y Colegio San Agustín de Avilés), Colegios Mayores de Madrid (Colegio Mayor Méndel y Colegio Mayor Elías Ahúja), al margen de otras vertientes de su actividad institucional como la expansión de la Provincia en América, la proyección parroquial en España y la atención a los Seminarios y otros focos de atención. Vid ÁLVAREZ TURIENZO, S., "Un genuino intelectual" en $A B C, 13 / 11 / 2008$; GARCÍA GRIMALDOS, M., "El Padre Gabriel del Estal, revitalizador de la Provincia Agustiniana Matritense del Sagrado Corazón de Jesús", en 222, 1 (2009), La Ciudad de Dios. Homenaje al P. Gabriel del Estal Gutiérrez (1917-2008), pp. 109-162.

${ }^{84}$ Sobre biografía y bibliografía del P. Gabriel del Estal vid. Analecta Augustiniana, Roma 21 (1947-50) 215; ALONSO TURIENZO, T., La Ciudad de Dios. Índices 1881-1960. San Lorenzo de El Escorial 1961, pp. 73-74; ÁLVAREZ TURIENZO, S., "Un genuino intelectual" en $A B C, 13 / 11 / 2008$; Boletín Informativo de la Provincia Agustiniana Matritense del Sagrado Corazón de Jesús, Madrid, 12 (dic. 1975) 208; n. especial (1982) 367-68; 7 (1986) 98-100; 11 (1994) 375-79; Catálogos de la Orden de S. Agustín, Roma 1994, p 502; CASTAÑO DE LA PUENTE, F., "In memoriam. P. Gabriel del Estal Gutiérrez (10.XI.2008)", en La Ciudad de Dios, 222, 1 (2009), La Ciudad de Dios Homenaje al P. Gabriel del Estal Gutiérrez (1917-2008), pp. 11-51; DÍAZ DÍAZ, G., Hombres y Documentos de la Filosofia Española, Vol. 3, Madrid 
2.- Fueron muchos los temas abordados por el P. Gabriel del Estal, pues fue un autor muy prolífico. Abordó numerosos temas sociales, que van a ser el eje alrededor del cual articula su obra jurídica, desde la autenticidad de la piedra escurialense a la que dedicó numerosos trabajos ${ }^{85}$. De su vasta bibliografía,

1980, pp. 74-80; DÍEZ FERNÁNDEZ, B., Historia del Real Colegio de Estudios Superiores, Universidad "Maria Cristina" de El Escorial, El Escorial 1960, pp. 189 y ss; FOLGADO FLÓREZ, S., "La producción literario-cultural de los agustinos en el Real Colegio de Estudios Superiores "María Cristina" del Escorial (1892-1992). Índice bibliográfico" en María Cristina de Habsburgo y los Estudios Superiores del Escorial. Cien años de Estudios Superiores, San Lorenzo de El Escorial 1992, pp. 525-37; FUEYO, A., Los Agustinos en la Revolución y en la Cruzada, Bilbao 1947, p. 323; GARCÍA VILLOSLADA, R., Historia de la Iglesia en España, vol. 5, Madrid 1979, p. 567; GONZÁLEZ VELASCO, M., Autores Agustinos de El Escorial, San Lorenzo de El Escorial 1996, pp. 289-316; ID., Autores Agustinos de El Escorial, San Lorenzo de El Escorial 2006, pp. 80-82; HERNÁNDEZ, L, "Nuevos colegios para nuevos tiempos. Entrevista con el P. Gabriel del Estal", en La Escuela Agustiniana, núm. 45/46, Abril-Dic. 1993, pp. 85-107; LLORDÉN SIMÓN, A., "Biobibliografía Agustiniana Escurialense", en La Comunidad Agustiniana en el Monasterio de El Escorial. Obra Cultural (1885-1963), San Lorenzo de El Escorial 1964, pp. 326-33; RODRÍGUEZ RODRÍGUEZ, I., y ÁLVAREZ FERNÁNDEZ, J., Labor CientíficoLiteraria de los Agustinos Españoles, Valladolid 1992, vol. 1, pp. 159-165; vol. 2, pp. 750-59; RODRÍGUEZ LLAMOSÍ, J. R., "El P. Gabriel del Estal en el recuerdo de un alumno", en Nueva Etapa, 77 (2010) 259-267; SCIACCA, M. F., La filosofia hoy. De los orígenes románticos de la filosofia contemporánea hasta los problemas actuales, Barcelona 1961, p. 424; VÁSQUEZ, A., Quién es quién en la Iglesia española, Madrid 1972, p. 103.

${ }^{85}$ DEL ESTAL. G., "El P. Jerónimo Montes en la penología española”, en La Ciudad de Dios, 1952, pp. 412-416; IDEM, "Turismo y filosofia: de San Quintín a El Escorial”, en Religión y Cultura, 3 (1958) 61-84; IDEM, “Arquitectura filológica de El Escorial”, en Hogar y Arquitectura, 1963, pp. 56-69; IDEM, "Arquitectura filológica de El Escorial. (II. Indagaciones sobre la Herrería)", en Número extraordinario de Nueva Etapa, El Escorial 1963, pp. 41-50; IDEM, "La Iglesia, Trento y El Escorial, en El Escorial. IV centenario de la fundación del monasterio de San Lorenzo el Real, 2 vols. Madrid: Patrimonio Nacional, 1963, vol. I, pp. 467-527; IDEM, "Los estudios superiores de San Lorenzo el Real. Memoria histórico-crítica sobre sus fundamentos y títulos en ambos Derechos" en El Escorial: Biblioteca "La Ciudad de Dios", 1964, pp. 1-48; IDEM, "El Escorial en la transición de San Jerónimo a San Agustín. Titularidad jurídica y circunstancia histórica", en Monasterio de San Lorenzo el Real. El Escorial. IV centenario de su fundación. El Escorial: Biblioteca "La Ciudad de Dios", 1964, pp. 561-616; IDEM, "Estado actual de las gestiones sobre el proyecto de Universidad Agustiniana Escurialense" en Boletín Informativo de la Provincia, 1 (1969) 17-22; IDEM, "Apéndice documental sobre el Real Colegio Universitario María Cristina", en Anuario Jurídico Escurialense, El Escorial 1971, pp. 441-506; IDEM, "Alfonso XII en El Escorial”, en Real Colegio de Alfonso XII. Primer Centenario, 1875-1975, El Escorial 1975, pp. 14-20; IDEM, "Las tres construcciones de El Escorial", en Los Domingos de $A B C, 18$ de diciembre de 1977, pp. 7-14; IDEM, "El Escorial y las Casas de Oficios", en Nueva Etapa, 1980, pp. 167-172; IDEM, "El Escorial: Urbanismo y naturaleza. 1. De la leal villa al Real Sitio", en Reales Sitios, 1982, pp. 45-68; IDEM, "El Escorial: Urbanismo y naturaleza. II. A. Razón histórica y lenguaje ecológico", en Reales Sitios, 1983, pp. 17-37; IDEM, "El Escorial: Urbanismo y naturaleza. II. B. Mística envolvente del bosque", en Reales Sitios, 1984, pp. 931; IDEM, "El Escorial, clave de Estado. Cesarismo pluralista de Felipe II, entre señoriazgo medieval y centralismo borbónico", en La Ciudad de Dios, 1984, pp. 623-674; IDEM, "Estudios superiores de El Escorial", en Los agustinos en el monasterio de El Escorial. San Lorenzo de El Escorial, Ediciones Escurialenses, 1985, pp. 80-95; IDEM, "Nuevo Escorial universitario. 
cercana a las 400 publicaciones, podemos concretar las aportaciones del sabio agustino al Derecho político español en cinco grandes temas, que consideramos son el eje nuclear de su pensamiento:

a. La realidad del objeto del Derecho político.

La primera cuestión que se plantea es: ¿Cuál es la realidad jurídica de la política? ¿Qué es la política como realidad social? Para el P. Gabriel del Estal, la realidad política parte de dos presupuestos: las formas sociales y el Derecho natural ${ }^{86}$.

Sitúa, en primer lugar, la cuestión social como ámbito al que pertenece la política $^{87}$. Lo social es, a juicio del P. Gabriel del Estal, una denominación genérica para las disciplinas o campos del saber que reclaman para sí mismas la condición de ciencias, que analizan y tratan distintos aspectos de los grupos sociales y de los seres humanos en sociedad.

Pero la realidad del Derecho no solo es su contexto social, sino también consiste en la libertad. Y en este sentido, el Derecho natural es la forma de la libertad. En el Derecho natural no cabe la reducción normativista del Derecho a la ley ${ }^{88}$. El P. Gabriel del Estal señala que el Derecho natural procede de la Ley natural según la concepción de la Escolástica tradicional y de Aristóteles, donde la Ley natural no es propiamente Derecho, sino moral ${ }^{89}$. Por tanto, para definir la realidad del Derecho político, el P. Gabriel del Estal no parte del Derecho positivo, sino del Derecho natural, de lo metajurídico, como aquello que permite conocer su contenido social. El P. del Estal llama a este proceso "desdivinización del Derecho"

I Centenario de los agustinos en el monasterio de San Lorenzo el Real", en La Ciudad de Dios, 1985, pp. 413-512; IDEM, "El Escorial: La Semana Santa del monasterio", en Reales Sitios, 1985, pp. 37-57; IDEM, Nuevo Escorial Universitario. El Escorial: Ediciones Escurialenses, 1986.

${ }^{86}$ DEL ESTAL, G., "Lo social y las ciencias sociales", en La Ciudad de Dios, 1950, pp. 5-60.

${ }^{87}$ DEL ESTAL. G. "Política ¿para qué?”, en LEA (La Escuela Agustiniana), 4 (1979) 41-43.

${ }^{88}$ DEL ESTAL, G., "Lo jurídico y lo metajurídico", en La Ciudad de Dios, 164 (1952) 467512; 165 (1953) pp. 33-101. Según dice el autor en nota de la p. 33, el art. anterior "corresponde a los apartados $1^{\circ}, 2^{\circ}, 3^{\circ}, 4^{\circ}$ y $5^{\circ}$ del trabajo en conjunto. El apartado $6^{\circ}$ ha salido también a la luz, pero independientemente" como se ha anotado anteriormente en 1952: IDEM, Lo jurídico y lo metajurídico", II. Derecho natural y Teología: Desdivinización del derecho en el área del iusnaturalismo protestante y retroceso hacia el racionalismo de la filosofia estoica", en Revista de Estudios Politicos, Madrid 1941-1942, pp. 133-149.

${ }^{89}$ DEL ESTAL, G., "Derecho natural y Teología", en Revista de Estudios Políticos, vol. XLV, núm. 65, Madrid 1952, pp. 152 y ss.

${ }^{90}$ DEL ESTAL, G., "Derecho natural y Teología: Desdivinización del derecho en el área del iusnaturalismo protestante y retroceso hacia el racionalismo de la filosofía estoica", en Revista de Estudios Políticos, Madrid 1941-1942, p. 144. 
b. El derecho a la vida, la institución familiar y la educación.

A partir de la década de los años 80 se suscitó en España un intenso debate sobre la institución familiar con todo lo que ello implica, singularmente el derecho a la vida y la educación de la juventud, que dio lugar a la puesta en marcha de sucesivas reformas legislativas.

El P. Gabriel del Estal, sensible a la discusión social, política y jurídica sobre la familia, dedicó numerosas páginas de su bibliografía a abordar el tema, comprometiéndose con posiciones conservadoras por las políticas públicas de defensa de la familia institucionalizada por el matrimonio indisoluble, como institución básica y fundamental de la sociedad conforme a la naturaleza humana, con exclusión de otros tipos de agrupación, y en aras a la consecución del bien común pues, por la familia, defiende el sabio agustino, comienza propiamente la sociedad.

El primero de los ejes de la familia para el P. Gabriel del Estal es el derecho a la vida y la institución familiar ${ }^{91}$. El P. Gabriel del Estal fue un rotundo defensor de la vida, oponiéndose a cualquier manifestación de supresión de ésta ${ }^{92}$. Y el otro gran eje de la familia es la educación religiosa de la juventud frente a los movimientos contraculturales ${ }^{93}$. En este sentido, el pensamiento del P. Gabriel del Estal sobre la familia remite a una concepción política de ésta en la que los padres tienen el deber de educar a los hijos y éstos de escuchar y obedecer a sus padres, pero también destaca la importancia de transmitir mediante la educación religiosa una ética que permita superar el nihilismo y el escepticismo y posibilite el desarrollo de una cierta autonomía moral en los jóvenes ${ }^{94}$.

c . La Monarquía: el Rey, sagrado e inviolable.

Hablar en nuestros días de la Monarquía es una empresa fácil, sobre todo porque es una institución mayoritariamente asentada entre el pueblo, reconocida

${ }^{91}$ DEL ESTAL, G., "La familia entre la persona y el Estado. Instituciones y libertades", en Nueva Etapa, 1977, pp. 69-79.

${ }^{92}$ DEL ESTAL, G., "El derecho a la vida", en Crítica, 660 (1978) 12-16; ID., Derecho a la vida e institución familiar. Aportación crítica al desarrollo de la nueva Constitución española. Prólogo del Doctor Botella Llusiá. Madrid 1979; IDEM, "Sí a la vida, no al aborto", en Magisterio Español, 16 de noviembre de 1979, pp. 20-23; IDEM, "Política de guerra y derecho de paz ante el derecho a la vida”, en Anuario Jurídico Escurialense, 12 (1980) 185-222.

${ }^{93}$ DEL ESTAL, G., "Los movimientos contraculturales de nuestra sociedad inconforme en el triple campo de la Juventud, la Universidad y la Iglesia". Conferencia de prensa celebrada el 7 de abril de 1973 en la Sala de Juntas del Instituto de la Juventud. Revista del Instituto de la Juventud, 47 (1973) 155-161.

${ }^{94}$ DEL ESTAL, G., Sociedad inconforme. Juventud. Universidad. Iglesia, Madrid 1973, pp. 171-176. 
por los ciudadanos y bien valorada en general, pero no era éste el contexto histórico cuando el P. Gabriel del Estal escribe acerca de la Monarquía.

El P. Gabriel del Estal escribió una gran obra: El rey, las Cortes y el reino ${ }^{95}$. Hasta la fecha se había escrito poco sobre el tema ${ }^{96}$. Su obra representaba en aquel momento, sin duda, la aportación más importante al Derecho político y una de las más sólidas reflexiones sobre la monarquía en España. Partiendo de sus ideas recogidas en pequeños retazos, llevó a cabo su adaptación al formato de un ensayo político, tomando en cuenta la nueva realidad de los acontecimientos, que salió a la luz pocos días antes de entrar en vigor la Constitución de 1978.

El P. Gabriel del Estal se había cuestionado el angustioso problema de la transición desde la dictadura al régimen constitucional y, desde su teoría constitucional, apreciaba la importancia que tenía la figura del Rey, sagrada e inviolable, en el Estado español, que habría de conciliarse con la división de poderes. De modo que la soberanía no era para el sabio agustino un mero ejercicio de gobernabilidad, sino de auge de un sistema constitucional. Por ello, analiza la evolución de la institución desde sus más remotos orígenes en España hasta el momento que escribe su obra, en 1978. Y, en vísperas de la que habría de ser la transición española, el P. Gabriel del Estal responde con

95 IDEM, El Rey, las Cortes y el Reino, El Escorial 1978.

96 Hemos encontrado las siguientes obras: DUVERGER, M., La Monarquía Republicana o cómo las democracias eligen a sus Reyes. Barcelona 1974; JIMENEZ DE PARGA Y CABRERA, M., "El Rey y el gobierno en Bélgica y Holanda", en José C. Castillo (et al.), Estudios en ciencia politica y sociología: homenaje al profesor Carlos Ollero. Madrid: (s.n), v. 1, 1972, pp. 329-360; IDEM, Las Monarquias europeas en el horizonte español. Madrid 1966; ALCORTA ECHEVARRÍA, J. I., "La Monarquía, España y Europa hoy", en Anales de la Real Academia de Ciencias Morales y Políticas, no 54 (1977) 113-150; BAR CENDÓN, A., "La Monarquía Parlamentaria como forma política del Estado Español según la Constitución de 1978", en Manuel Ramírez (ed.), Estudios sobre la Constitución Español de 1978. Zaragoza 1979, pp. 191-215; IDEM, "La monarquía parlamentaria como forma política del Estado español según la Constitución de 1978", en Manuel Ramírez: Estudios sobre la Constitución Española de 1978. Zaragoza 1979, pp.191-215; COLOMER VIADEL, A. "El origen de la Monarquía parlamentaria en España y el anteproyecto constitucional", en Revista de Estudios Políticos, n 3 (1978) 101-120; FERNÁNDEZ CAMPO, S., "La Monarquía y la Constitución de 1978", en Revista de Derecho Politico, no 44 (1978) 209-224; FERRANDO BADÍA, J. "La monarquía parlamentaria actual española", en Revista de Estudios Políticos, n 13 (1978) 7-44; FRAGA IRIBARNE, Manuel: "La Monarquía como forma del Estado", en Estudios de Ciencia Política y Sociología: Homenaje. Madrid 1972, pp. 187-206; HERRERO LERA, M., "La instauración monárquica en España: proceso jurídico-político de su conformación como monarquía parlamentaria", en Tomás Ramón Fernández Rodríguez (coord.): Lecturas sobre la Constitución española. Madrid: Universidad Nacional de Educación a Distancia, v. I, 1978, pp.181-202; OTTO Y PARDO, Ignacio de: "Sobre la Monarquía", en Gregorio Peces-Barba (dir.): La izquierda y la Constitución. Barcelona 1978, pp. 51-61; SÁNCHEZ AGESTA, L., "La legitimación popular de la Monarquía", en La Corona y la nueva sociedad española ante un año histórico: ciclo de conferencias pronunciadas en el Club Siglo XXI durante el curso 1976-1977, Madrid v. II (1977) 39-56. 
ésta obra a un problema que los constitucionalistas se habían planteado acerca de la importancia y funciones de la soberanía, distinguiendo entre la titularidad y el ejercicio de la soberanía, separando el poder constituyente de los poderes constituidos. El poder Constituyente, la Cortes generales, garantizan la unidad y permanencia del Estado, mientras que los poderes constituidos debían acomodarse su dirección política estatal a las circunstancias históricas ${ }^{97}$.

\section{d. El Cristianismo frente al Marxismo.}

En el año 1974, el P. Gabriel del Estal muestra su preocupación por un tema que será otro de los ejes de su pensamiento político y al que dedicará su atención: la convivencia cristiana, y escribe una interesante obra titulada: "Marxismo y cristianismo, ¿diálogo o enfrentamiento?",98.

Se trata de un estudio documentado sobre un tema de actualidad en el momento de su publicación como es el de las relaciones entre el marxismo y el Cristianismo. El P. Gabriel del Estal parte de una idea principal y es que, a su juicio, la Humanidad se halla dividida en torno a dos frentes de pensamiento y vida que son el marxismo y el Cristianismo. Ambos intentan interpretar la Historia, la sociedad y al hombre mismo. El P. Gabriel del Estal parte de la renuncia total al enfrentamiento: los anatemas hay que encerrarlos en el arca de la historia y custodiarlos celosamente para que no vuelvan a salir a la superficie.

Preocupado por la misión de la Iglesia en el fin de siglo ante el reto del marxismo y la necesidad de establecer la confesionalidad cristiana como religión oficial del Estado español, el P. Gabriel del Estal había expresado su preocupación tanto por el carácter universitario y educativo de ésta ${ }^{99}$, como por la necesidad de unidad en la Iglesia, cuya preocupación parte de una conciencia ecuménica y de la necesidad de la restauración de la unidad de los cristianos, es decir, la unidad de las distintas confesiones religiosas cristianas históricas, separadas desde los grandes cismas por cuestiones de doctrina, de historia, de tradición o de práctica como mecanismo para hacer frente a las tendencias desintegradoras del hombre moderno ${ }^{100}$.

${ }^{97}$ DEL ESTAL, G., El Rey, las Cortes y el Reino, El Escorial 1978, pp. 46-133.

${ }^{98}$ IDEM, Marxismo y cristianismo, ¿diálogo o enfrentamiento? Prólogo del cardenal Enrique Tarancón. Análisis preliminar de J. Prados Arrarte. El Escorial 1977.

${ }^{99}$ DEL ESTAL, G., "Invitación a la tolerancia”, en Educadores, 1 (1959) 703-716; ID., "Lovaina como magisterio. Actualidad, vocación de futuro y conciencia histórica", en Educadores, 2 (1960) 773-788.

100 DEL ESTAL, G., "Proyección panorámica de los concilios ecuménicos", en Concilio, Madrid 1962, pp. 8-10; IDEM, "Los concilios ecuménicos y el Vaticano II. 1. Nueva hora eclesial", en La Ciudad de Dios, 1962, pp. 251-292; IDEM, "Los concilios ecuménicos y el Vaticano II. (II. Perspectiva histórica conciliar), en La Ciudad de Dios, 1962, pp. 472-502; IDEM, Viento 


\section{e. La idea de la Justicia}

Otro de los grandes temas tratados en la amplia bibliografía del P. Gabriel del Estal es la idea de Justicia. Para elaborar su teoría parte de una conocida tragedia griega de Esquilo: la Orestiada y escribe un libro excepcional: " $L a$ Orestiada y su genio jurídico" ${ }^{\text {"101 }}$.

Se vale el P. Gabriel del Estal de la conocida tragedia de Esquilo de donde extrae materiales para el estudio del Derecho y la evolución de la idea de Justicia desde la Justicia de sangre a la Justicia de la razón. La tragedia le ofrece, sin duda, al gran jurista agustino, un gran número de temas sugestivos de donde extrae una valiosa investigación jurídica. Para el P. Gabriel del Estal, la Orestiada representa la humanización del Derecho con el tránsito de la Ley del Talión a la polis.

\subsection{P. Avelino Folgado Fernández (1917-2013)}

1.- Agustino. Doctor en Derecho, fue discípulo del ilustre civilista Federico de Castro y Bravo. Rector de los Estudios Superiores del Escorial y profesor de Derecho civil $^{102}$.

de Pentecostés en el monte Vaticano. La paz del Concilio, paz ecuménica de salvación, El EscorialMadrid-Buenos Aires, 1962; IDEM, "Ecumenismo y fe radical", en La Ciudad de Dios, 1964, pp. 100-110; IDEM, "Libertad y comunidad en la Iglesia", en Ecclesia, Madrid, 1971, pp. 5153; IDEM, "Iglesia y sociedad: pautas de renovación", en La Ciudad de Dios, 1971, pp. 365393; IDEM, "Seglarismo y sacerdocio", en Ecclesia, Madrid, 1971, pp. 1153-1155; IDEM, "Creer con esperanza. Apostillas a una denuncia sin testigos", en La Ciudad de Dios, 1973, pp. 395-407; IDEM, "Esperanza y salvación: la gran nostalgia del hombre unidimensional", en Anales de moral social y católica, 33. Economía de consumo y sociedad, Centro de Estudios Sociales del Valle de los Caídos, 1973, pp. 203-254; IDEM, "Iglesia imperfecta e iglesia perfectible" en Ecclesia, Madrid, 1973, pp. 1235-1237; IDEM, "Del nacional-catolicismo al estado laico", en Ecclesia, Madrid, 1981, pp. 1099-1101; ID, "Iglesia y Constitución política en España", en La cuestión social en la iglesia española contemporánea. IV-V Semana de Historia eclesiástica de España, El Escorial, 1981, pp. 285-332; IDEM, "Iglesia y Constitución política en España. 1. Exposición sistemática. 2. Exposición analítica. 3. Bibliografía básica con clasificación de materias por especialidad de campos y tipos", en Anuario Jurídico Escurialense, 13 (1981) 257-328; IDEM, "Iglesia y poder político en la España constitucional". Conferencia pronunciada en el "Club Siglo XXI" el 12 de marzo de 1981, en Fenómenos de crisis y futuro de España, Madrid, vol. III (1981) 99-129.

${ }^{101}$ DEL ESTAL, G., La Orestiada y su genio jurídico. Justicia de sangre y espiritu urbano. Aportación desde la tragedia a la historia de la filosofía del derecho, de la religión y de la sociedad en el mundo antiguo. Prólogo de J. Camón Aznar. El Escorial 1962. Previamente se publicó en partes como: IDEM, "La Orestiada y su genio jurídico", en La Ciudad de Dios, Madrid 1960, pp. 268-318; IDEM, "La Orestiada y su genio jurídico. De la justicia erínnica a las Euménides de la ciudad”, en La Ciudad de Dios, 1960, pp. 444-502.

102 Sobre biografía y bibliografía del P. Avelino Folgado vid. GONZÁLEZ VELASCO, M., Autores Agustinos de El Escorial, San Lorenzo de El Escorial 1996, pp. 351-352; ID., 
2.- No fue el P. Avelino Folgado un autor prolífico. Apenas media docena de trabajos jurídicos forman su haber intelectual, pero los que realizó, en especial en el ámbito del derecho subjetivo, merecen ser tenidos en consideración en el ámbito del Derecho civil, por lo que suponen de aportación a la Ciencia jurídica española.

En el año 1959 publicó un trabajo corto, pero interesante, que supuso una primera toma de conciencia del problema que en el Derecho civil representaba el concepto de derecho subjetivo titulado: La controversia sobre la pobreza franciscana bajo el pontificado de Juan XXIII y el concepto de derecho subjetivo ${ }^{103}$. Tras plantear el problema de los términos jurídicos relativos al uso del derecho y las ideas romanas que lo configuran como objeto, se centró en la controversia con el Papado a razón de la disputa sobre la propiedad que mantuvieron los franciscanos, fieles a su regla monástica, y la posición de Guillermo de Occam, analizando los documentos pontificios sobre la cuestión de los que surge el concepto de derecho subjetivo.

También, en 1959, publicó un segundo trabajo titulado: Los tratados De legibus y de iustitia et iure en los autores españoles del siglo XVI y primera mitad del XVII, con el que prepararía su tesis doctoral y principal aportación del P. Avelino Folgado al Derecho civil ${ }^{104}$.

Estos dos primeros trabajos sirvieron al P. Avelino Folgado de recogida de material y preparación para su obra más importante, publicada en 1960, que presentó en la Universidad Central de Madrid como tesis doctoral con la que obtuvo el grado de doctor titulada: "Evolución histórica del concepto de

Autores Agustinos de El Escorial, San Lorenzo de El Escorial 2006, pp. 87-88; Analecta Augustiniana, Roma 21 (1947-50) 215; Boletín Informativo de la Provincia Agustiniana Matritense del Sagrado Corazón de Jesús, Madrid (1986) 100; 11, p. 381; Catálogos de la Orden de S. Agustín, Roma 1994, p 508; FOLGADO FLÓREZ, S., "La producción literariocultural de los agustinos en el Real Colegio de Estudios Superiores "María Cristina" del Escorial (1892-1992). Índice bibliográfico", en Maria Cristina de Habsburgo y los Estudios Superiores del Escorial. Cien años de Estudios Superiores, San Lorenzo de El Escorial 1992, pp. 537-39; LLORDÉN SIMÓN, A., "Biobibliografia Agustiniana Escurialense", en La Comunidad Agustiniana en el Monasterio de El Escorial. Obra Cultural (1885-1963), San Lorenzo de El Escorial 1964, pp. 347-48; RODRÍGUEZ RODRÍGUEZ, I., y ÁLVAREZ FERNÁNDEZ, J., Labor CientificoLiteraria de los Agustinos Españoles, Valladolid 1992, vol. 1 pp. 202-203; vol. 2, p. 780.

${ }^{103}$ FOLGADO FERNÁNDEZ, A., "La controversia sobre la pobreza franciscana bajo el pontificado de Juan XXII y el concepto de derecho subjetivo", en La Ciudad de Dios, 172 (1959) 73-133. También formando parte del volumen DEL ESTAL, G., La dialéctica de los dos reinos, San Lorenzo de El Escorial 1959, pp. 73-133.

${ }^{104}$ FOLGADO FERNÁNDEZ, A., "Los tratados De legibus y de iustitia et iure en los autores españoles del siglo XVI y primera mitad del XVII, en La Ciudad de Dios, 172 (1959) 275-302. Se advierte una mala paginación de la revista y deben ser las páginas 457-484. 
Derecho subjetivo. Estudio especial de los teólogos-juristas españoles del siglo XVI"105.

En estos trabajos sitúa el origen del concepto de derecho subjetivo en la controversia sobre la pobreza franciscana, y desarrolla la labor que hicieron los primeros representantes de la teología española del Siglo de oro para unir la Escolástica del siglo XIII con el Humanismo renacentista del siglo XVI, evitando repetir sin más sus especulaciones teóricas para proyectarse a la realidad y dar una adecuada respuesta a los nuevos problemas que planteaban las nuevas circunstancias.

El P. Avelino Folgado descubrió también en aquellas investigaciones que lo que Guillermo de Occam establecía para poder resolver la controversia franciscana sobre la pobreza era una distinción entre ius fori e ius poli, expresiones agustinianas que Occam empleará como sinónimas, respectivamente, de derecho positivo-humano y de derecho natural-racional. A este aspecto dedicará el $\mathrm{P}$. Avelino interesantes monografías que analizan el concepto de propiedad en San Agustín ${ }^{106}$, a los que sumaría otros estudios sobre diferentes aspectos del Derecho civil ${ }^{107}$.

Su obra esencial, como decimos, publicada en 1960, se titula: "Evolución histórica del concepto de Derecho subjetivo. Estudio especial de los teólogosjuristas españoles del siglo XVI"108. En ella sitúa el origen del concepto de derecho subjetivo en la controversia franciscana sobre la pobreza que tuvo lugar en el siglo XIV poniendo fin a las discusiones doctrinales acerca del origen del concepto del derecho subjetivo.

${ }^{105}$ IDEM, Evolución histórica del concepto de Derecho subjetivo. Estudio especial de los teólogos-juritas españoles del siglo XVI, San Lorenzo de El Escorial 1960, Tirada aparte en Anuario Jurídico y Económico escurialense, 1 (1960) 17-330.

${ }^{106}$ FOLGADO, A., "Terminología del derecho de propiedad en San Agustín”, en Anuario Jurídico y Económico Escurialense, 29 (1996), pp. 9-37; ID, "Controversia pelagiano-agustiniana sobre la salvación de los ricos", en La Ciudad de Dios, 211 (1998) 403-475; ID, "La Ley y el Derecho en San Agustín", en Anuario Jurídico y Económico Escurialense, 31 (1999) 11-46; y ID, El pensamiento de San Agustín en torno a la propiedad privada, San Lorenzo de El Escorial 2003.

107 FOLGADO FERNÁNDEZ, A., "Los derechos del escritor y del artista según los moralistas y canonistas españoles de la primera mitad del siglo XVII", en Anuario Jurídico y Económico Escurialense 2 (1961) 331-77; ID., "La doctrina jurisprudencial del abuso del Derecho", en Anuario Jurídico y Económico Escurialense, 12 (1980) 223-377; y ID., "La figura de la prodigalidad en el Código Civil, después de la ley de 24 de octubre de 1983", en Anuario Jurídico y Económico Escurialense, 16 (1984) 15-48.

${ }^{108}$ IDEM, Evolución histórica del concepto de Derecho subjetivo. Estudio especial de los teólogos-juritas españoles del siglo XVI, San Lorenzo de El Escorial 1960, Tirada aparte en Anuario Jurídico y Económico escurialense, 1 (1960) 17-330. 
Cuando San Francisco de Asís funda su Orden, en el año 1209, propone que sus "frailes menores" se atengan taxativamente a las instrucciones de pobreza que Jesús transmitió a sus apóstoles al enviarlos a predicar. Lo que San Francisco pretendía era que los franciscanos vivieran al margen del Derecho, renunciando a sus derechos individuales tanto sobre bienes materiales (propiedad) como sobre los inmateriales (poder, honor).

Sin embargo, las cosas no eran realmente así. Tanto antes de la muerte de San Francisco como después de acaecida ésta, los franciscanos recibieron privilegios de la Santa Sede, nombraron autoridades de la Orden, y en general, retornaron al Derecho aun cuando seguían negándolo. De hecho, a la muerte de San Francisco, se comenzó la construcción de un lujoso templo y centro de peregrinaje en su memoria, para lo cual se recibieron importantes limosnas, aparecieron iglesias y grandes conventos franciscanos en toda Europa, y tuvieron necesidad de personal de servicio, jardineros, cocineros, etc.

En esta línea, el Papa Gregorio IX promulgó el 29 de septiembre de 1230 la Bula Quo elegante según la cual los franciscanos tienen solamente el "uso" de los bienes que están a su disposición, pero no la propiedad, que corresponde directamente al Papado (in ius et proprietatem Beati Petri).

Esta situación se hizo insostenible y comenzaron las críticas en torno al Papa. Además, a finales del siglo XIII, aparecieron en Italia y en el sur de Francia ciertos franciscanos extremistas llamados "Espirituales" que regresaron al culto a la pobreza y no admitían sino el "uso pobre" ("usus pauper") de los bienes materiales.

En medio de esta revuelta aparece un franciscano, venido de Oxford, llamado Guillermo de Occam (o de Ockham) (1285-1349) que se coloca del lado de sus hermanos perseguidos y ataca las tesis del Papa Juan XXII en una serie de escritos polémicos, entre los que destaca el Opus nonaginta dierum (1332), llamado así porque fue escrito en noventa días. Su argumentación se basaba en la afirmación de que el derecho individual no es un simple derecho, sino el poder de beneficiarse: todo derecho implica una idea de poder subyacente que puede ser ejercitado por el titular. En cambio, los franciscanos, como lo hizo Jesús, se limitan a usar sin tener poder de hacerlo: tienen el goce, pero no el título del goce. Por tanto, no pueden acogerse a los remedios que son la esencia de todo derecho individual: la potestas vindicandi et defendendi in humano iudicio.

El P. Avelino señaló que en la controversia franciscana sobre la pobreza se encuentra el origen del concepto del derecho subjetivo desarrollado en el siglo XVI en la segunda escolástica hispana y, concretamente, por los teólogos Juan de Gerson, Juan Mayr, Conrado Summenhart de Calw y Juan Driedo de Turnhout. 
3.- Aunque el filósofo del Derecho e historiador de las ideas jurídicas, el profesor francés Michel Villey, mantuvo que la atribución del significado de "facultad" o "potestad" a la palabra "derecho" tuvo sus orígenes precisos en el pensamiento del filósofo y teólogo inglés Guillermo de Occam, sin embargo, mucho antes el P. Avelino Folgado estableció una nueva concepción del tema según la cual la noción del derecho subjetivo resulta haber sido una creación de los franciscanos del siglo XIII que habría permitido a Guillermo de Occam elaborarla a partir de las ideas que ya estaban en el propio ambiente.

\section{5. P. Prometeo Cerezo de Diego (1938)}

1.- Agustino. Licenciado en Ciencias Políticas (sección de Estudios internacionales) y doctor en Derecho. Profesor titular de Derecho Internacional Público en la Facultad de Derecho de la Universidad Complutense de Madrid; Decano de Derecho del Real Centro Universitario "María Cristina" de El Escorial; Secretario General del Instituto Hispano-Luso-Americano de Derecho Internacional y Vicepresidente de la International Law Asociation (sección española). Académico de número de la Academia Interamericana de Derecho Internacional y Comparado, con sede en Lima. Director del Anuario HispanoLuso-Americano de Derecho Internaciona ${ }^{109}$.

Ha pronunciado conferencias en numerosos y distinguidos foros y Congresos, nacionales e internacionales, tanto en Europa como en América, Asia y Filipinas. También ha sido un asiduo colaborador en prestigiosas revistas científicas como la Revista Española de Derecho Internacional; Anuario Jurídico y Económico Escurialense; Revista de Filosofia de la Universidad Iberoamericana; La Ciudad de Dios; y el Anuario Hispano Luso Americano de Derecho Internacional que, bienalmente, edita el Instituto Hispano-LusoAmericano de Derecho Internacional y del que ha sido director desde el año 1989. Posee además diferentes condecoraciones de ámbito tanto nacional como internaciona ${ }^{110}$.

${ }^{109}$ Merecen destacarse por su importancia: Orden de ANDRÉS BELLO, en la Clase de BANDA DE HONOR, por el Estado de Venezuela (Gaceta Oficial de la República de Venezuela $n^{\circ}$ 34.682, p. 277.054. Caracas, lunes 25 de marzo de 1991); Diploma de "Huésped Distinguido de la ciudad de Mérida" (Venezuela), 18 de marzo de 1991; Insignia de Plata "Melero Alcarreño" (11-XII1992); Popular de Nueva Alcarria. Año 1992; Medalla de plata "Premio al Mérito Docente", Muy Ilustre Ayuntamiento del Real Sitio de San Lorenzo de El Escorial, 10 de agosto de 2005; Medalla de plata del Real Centro Universitario "Escorial-M ${ }^{a}$ Cristina", 17 de mayo de 2008; Placa de Plata de los alumnos de Derecho internacional público, Grupo "P”, del curso 20072008, de la Facultad de Derecho de la Universidad Complutense de Madrid; Diploma de "Huésped de Honor" por la Universidad Nacional de Córdoba (Argentina), 22 de septiembre de 2008; Medalla de plata de la Universidad Complutense de Madrid por los servicios prestados, 1 de octubre de 2008; Caballero de la Orden de Rizal, por el Estado de Filipinas (Manila, 27 de junio de 2012).

${ }^{110}$ Sobre biografía y bibliografía del P. Prometeo Cerezo de Diego vid. GONZÁLEZ VELASCO, M., Autores Agustinos de El Escorial, San Lorenzo de El Escorial 1996, pp. 222- 
2. Sus aportaciones al Derecho Internacional Público se concretan en tres aspectos:

2.1.- Como secretario general del Instituto Hispano-Luso-Americano de Derecho Internacional, ha organizado desde el año 1989 más de una docena de Congresos en diferentes ciudades y lugares del mundo contribuyendo al desarrollo y difusión del Derecho internacional.

Asimismo, el P. Prometeo Cerezo de Diego ha sido Director del Anuario del Instituto desde 1991 hasta 2014, a través de los cuales ha promovido la difusión y el conocimiento del Derecho internacional.

2.2.- En su aspecto monográfico destacan sus estudios sobre los problemas derivados de la Conquista de América, que culminarán en la que puede considerarse su obra más importante titulada: Alonso de Veracruz y el derecho de gentes ${ }^{111}$, que fue su tesis doctoral galardonada con el Premio internacional "Luis García Arias" del Instituto Hispano-Luso-Americano de Derecho Internacional, en la que expone la postura de Alonso de Veracruz sobre la Conquista de América. Nuestro sabio agustino no sólo realiza una cabal introducción sobre la vida y la obra de Fray Alonso de Veracruz, sino que permite situar el marco jurídico de la Conquista de América, conocer las tesis de los escolásticos y las diferencias entre Alonso de Veracruz y su maestro, Francisco de Vitoria, así como una minuciosa investigación de las causas, justificantes e injustificantes, de la Conquista según la posición de Veracruz ${ }^{112}$ :

a. El marco jurídico de la Conquista de América. Son numerosas las páginas, de deleitosa lectura, que dedica a analizar y desarrollar el marco jurídico de la Conquista de América con el que se encontró fray Alonso de Veracruz al

225; ID., Autores Agustinos de El Escorial, San Lorenzo de El Escorial 2006, pp. 57-60; Boletín Informativo de la Provincia Agustiniana Matritense del Sagrado Corazón de Jesús, Madrid 11 (1994) 368-369; Catálogos de la Orden de S. Agustín, Roma 1994, p. 484; FOLGADO FLÓREZ, S., "La producción literario-cultural de los agustinos en el Real Colegio de Estudios Superiores "María Cristina" del Escorial (1892-1992). Índice bibliográfico", en María Cristina de Habsburgo y los Estudios Superiores del Escorial. Cien años de Estudios Superiores, San Lorenzo de El Escorial 1992, pp. 521-24; RODRIGUEZ RODRÍGUEZ, I. y ÁLVAREZ FERNÁNDEZ, J., Labor Científico-Literaria de los Agustinos Españoles, Valladolid 1992, vol. 2 pp. 712-14.

${ }^{111}$ CEREZO DE DIEGO, P., Alonso de Veracruz y el Derecho de gentes, México 1985, pp. XXXI +372 .

${ }^{112}$ Así lo apunta otro prestigioso y destacado compañero de hábito agustino, el P. Francisco Javier Campos y Fernández de Sevilla, quien señala que los abundantes estudios del P. Prometeo Cerezo de Diego son punto de referencia en la bibliografia veracruciana. Para un examen completo sobre la biografía veracruciana, vid. CAMPOS, J., "Bibliografía de y sobre fray Alonso de Veracruz, OSA", en VELASCO GÓMEZ, A., (coord.), Fray Alonso de la Veracruz: universitario, humanista, científico y republicano", México 2009, pp. 307-357. 
elaborar su tratado De dominio infidelium et iusto bello y profundiza en los aspectos legales y jurídicos de aquella.

b. Las tesis de los escolásticos. Un segundo e importante tema que ha estudiado y analizado en profundidad el P. Prometeo Cerezo de Diego, y de obligada referencia en el marco del Derecho de gentes, es la posición de las tesis de la Escuela de Salamanca con ocasión de la Conquista de América, que no sólo se refieren a aspectos teológicos sino, lo más importante para nuestra tesis, a los jurídicos.

c. La posición de Alonso de Veracruz sobre la Conquista de América. Tras exponer la biografía de Veracruz señala las diferencias entre Francisco de Vitoria y Alonso de Veracruz y expone las cuestiones o dudas suscitadas por Alonso de Veracruz con motivo de la Conquista de América.

A partir de ese trabajo, de gran calado científico, el P. Prometeo publicó con regularidad numerosos estudios, centrados todos en la figura de Veracruz, con quien comparte ser alcarreño, el hábito de agustino y la pasión por el Derecho de gentes, $\mathrm{y}$ en los cuales, desde diferentes perspectivas, aborda estudios sobre la figura del misionero y evangelizador agustino y el importante papel desempeñado por el mismo en la Conquista de América ${ }^{113}$.

${ }^{113}$ En este ámbito, destacan los siguientes trabajos: CEREZO DE DIEGO, P., "Polémica sobre la legitimidad de la conquista de México", en Actas del I Congreso Internacional sobre Hernán Cortés, Editorial Universidad de Salamanca, 1986, pp. 299-312; IDEM, "El pensamiento americano de un discípulo de Vitoria: Alonso de Veracruz", en I Diritti dell'uomo e la pace nel pensiero di Francisco de Vitoria e Bartolomé de Las Casas. Congreso Internazionale tenuto alla Pontificia Università S. Tomasso (Angelicum), Roma 4-6 marzo 1985, Massimo, Milano 1988, pp. 255-272; IDEM, "La influencia de las ideas de la Escuela de Salamanca en América", en Colloquia Europalia, IV. L'Espagne et la formation du Droit des Gens moderne. Acta Colloquii Bruxellensis 22-X-1985, In aedibus Peeters, Lovanii 1988, pp. 47-56; IDEM, "Influencia de Alonso de Veracruz, O.S.A., en la Universidad de México", en Actas del Congreso Internacional V Centenario. AGUSTINOS EN AMERICA Y FILIPINAS, Valladolid 1990, pp. 385-411; IDEM, "Fray Luis de León y Fray Alonso de Veracruz", en Fray Luis de León. IV Centenario (1591-1991). Congreso interdisciplinar Madrid 1991. Actas, Real Monasterio de El Escorial 1992, pp. 425-432; IDEM, "Estudios sobre Fray Alonso de la Veracruz y dos obras suyas Physica speculatio y De decimis", en La Iglesia en América: Evangelización y Cultura, Catálogo del Pabellón de la Santa Sede, Sevilla 1992, pp. 298-300; IDEM, "Alonso de Veracruz, O.S.A., y la introducción del Derecho de Gentes en México", en La familia agustiniana en la EXPO 92. FAE Boletín Informativo, Madrid 1992, pp. 23-27; IDEM, "El manuscrito Relectio de decimis de fray Alonso de Veracruz, O.S.A.”, en Anuario Jurídico y Económico Escurialense, 25 (1993) 609-623 y en la obra colectiva Fondo manuscrito americano de la biblioteca de San Lorenzo del Escorial, San Lorenzo de El Escorial 1993, pp. 197-211; IDEM, "Los métodos misionales de Evangelización de América. Un modelo intermedio: Fray Alonso de Veracruz", en La Iglesia en América: siglos XVI-XX, Sevilla 1992, pp. 175-189; IDEM, "La fundación de la Real y Pontificia Universidad de México y la formación y selección de 


\section{3.- La Escuela escurialense de Derecho internacional}

Fruto de la pasión y el entusiasmo del P. Prometeo Cerezo de Diego por el Derecho internacional y una gran aportación al mismo constituye la creación por el sabio agustino de la llamada "Escuela escurialense de Derecho internacional" a la que pertenecen un grupo de discípulos, en su mayoría alumnos procedentes de sus años de docencia en la Universidad "María Cristina" de El Escorial, que a lo largo de los años se han formado y especializado siguiendo sus directrices ${ }^{114}$.

Entre las características que comparte esta escuela se encuentran:

- La relación interdisciplinar.

- La preferencia por el trabajo en grupo, compartiendo esfuerzos y resultados, y actuando en lo posible como un colectivo identificado en la comunidad universitaria.

- La vocación docente.

- El carácter eminentemente crítico de sus investigaciones, tratando temas de enorme actualidad y muy controvertidos social y jurídicamente.

- La vocación agustiniana de servicio a la sociedad, implicándose en la gestión universitaria en diferentes responsabilidades.

- La reivindicación de su formación agustiniana y del legado escurialense.

- La guía universitaria del P. Prometeo Cerezo de Diego.

A este grupo pertenecen, juristas destacados, todos ellos discentes de El Escorial y discípulos del P. Prometeo Cerezo de Diego, y todos ellos destacados especialistas en Derecho internacional público y privado: Modesto Barcia Lago; Eugenio Pérez de Francisco; José Antonio Perea Unceta; Rubén Carnerero Castilla; María José Lunas Díaz; y Clara Isabel Cordero Álvarez.

\footnotetext{
las primeras cátedras", en La universidad ante el Quinto Centenario. Actas del Congreso Internacional de Universidades. Madrid 13-16 de julio de 1992, Edit. Complutense, Madrid 1993, pp. 249-257; IDEM, "Alonso de Veracruz, OSA (1507-1584): misionero, formador, catedrático y defensor de los indios", en La Familia Agustiniana en Contextos de Globalización, Centro Teológico San Agustín, Madrid 2003, pp. 157-172; IDEM, "Fray Alonso de Veracruz a los 500 años de su nacimiento (1507-2007)", en Boletín Informativo, vol. XX, núm. 162, junio 2008, pp. 637-641; IDEM, "Alonso de la Veracruz y su maestro Francisco de Vitoria", en Fray Alonso de la Vera Cruz: universitario, humanista, cientifico y republicano, UNAM, México 2009, pp. 19-45.

${ }^{114}$ A este grupo se refirió el P. Prometeo Cerezo de Diego, con ocasión del Pregón de las Fiestas Patronales de San Lorenzo de El Escorial, que pronunció en el año 2005, invitado por la Concejalía de Fiestas del Ayuntamiento de San Lorenzo de El Escorial.
} 


\section{CONCLUSIÓN}

Concluyo la defensa de mi tesis doctoral con una reflexión, una fe de erratas; y un recuerdo especial.

1.- Reflexión: ¿Por qué son importantes estas aportaciones?

La ciencia jurídica se nutre con la reflexión de los juristas.

En las obras de estos sabios agustinos juristas de El Escorial hay muchas reflexiones jurídicas, mucho material técnico, muchas ideas y muchos pensamientos de contenido académico. No son obras improvisadas ni de principiantes, sino textos que merecen un reconocimiento que no consiguieron. Hace muchos años que fueron escritas, pero su contenido constituye una base firme y sólida que debe tenerse en cuenta en la Ciencia jurídica española y que he querido rescatar porque, a los que amamos el Derecho, nos enriquecen.

Léanse cualquiera de las obras que he citado donde los agustinos exponen sus estudios, las investigaciones que llevaron a cabo expuestas con esfuerzo, con tesón, con pasión, y se comprenderá porqué el nombre de estos agustinos juristas de El Escorial y sus obras, han de sobrevivir al injusto olvido en el que ahora permanecen.

\section{2.- Fe de erratas.}

Para pedir disculpas por algunas erratas de la tesis que han asomado su hocico después de publicada. Algunas son puramente ortográficas, y merecen mi disculpa pública, pero otras, de más calado, como la desaparición inadvertidamente de la nota a pie de pág. de la pág. 77, merecerían la hoguera, así que permítanme que la subsane ahora a fin de evitar la pira. Se trata de una cita de Santiago Valentí Camp, tomada de su obra "Ideólogos, teorizantes y videntes", publicada en Madrid en 1922.

\section{3.- Recuerdo especial.}

Termino con un recuerdo especial para mi padre. Él falleció hace unos años en un accidente de tráfico y estoy completamente seguro que habría estado hoy aquí conmigo, aunque presiento que de algún modo lo está porque, por esas cosas de la Providencia, hoy es día 28 que es el número del día en que él falleció. Él fue quien me llevó al Escorial cuando yo era un muchacho de apenas 18 años recién cumplidos, me dejó en la puerta de la Universidad 
"María Cristina", me abrazó, puso su mano sobre mi hombro, y me dijo: "Hijo mio, aprovecha lo que los profesores te enseñen durante el día, para que lo que emprendas en tu vida el día de mañana te permita dormir tranquilo durante la noche". Les puedo asegurar que, a pesar de haber obedecido siempre a mi padre, esta tesis me ha quitado el sueño muchas noches, pero espero que haya servido para que estos sabios agustinos juristas de El Escorial, a los que me he referido en ella, tengan ahora el reconocimiento y el sueño eterno que merecen.

Muchas gracias a todos por su atención.

Quedo a su disposición para cualquier aclaración que precisen. 
